\title{
Potential of Using Ginger Essential Oils-Based Nanotechnology to Control Tropical Plant Diseases
}

\author{
Adamu Abdullahi ${ }^{1,2}$, Khairulmazmi Ahmad ${ }^{2,3,4 *}$, Intan Safinar Ismail ${ }^{5}$, Norhayu Asib $^{2}$, Osumanu Haruna \\ Ahmed $^{6,7}$, Abubakar Ismaila Abubakar ${ }^{8}$, Yasmeen Siddiqui ${ }^{3 *}$, and Mohd Razi Ismail ${ }^{4}$ \\ ${ }^{1}$ Department of Biological Sciences, Faculty of Science, Sokoto State University, P.M.B 2134, Birnin Kebbi Road, \\ Sokoto State, Nigeria \\ ${ }^{2}$ Department of Plant Protection, Faculty of Agriculture, Universiti Putra Malaysia, 43400 Serdang, Selangor Darul \\ Ehsan, Malaysia \\ ${ }^{3}$ Institute of Plantation Studies (IKP), Universiti Putra Malaysia, 43400 Serdang, Selangor Darul Ehsan, Malaysia \\ ${ }^{4}$ Institute of Tropical Agriculture and Food Security (ITAFoS), Universiti Putra Malaysia, 43400 Serdang, Selangor \\ Darul Ehsan, Malaysia \\ ${ }^{5}$ Department of Chemistry, Faculty of Science, Universiti Putra Malaysia, 43400 Serdang, Selangor Darul Ehsan, \\ Malaysia \\ ${ }^{6}$ Department of Crop Science, Faculty of Agriculture and Food Sciences, Bintulu Campus Sarawak, Universiti Putra \\ Malaysia, 97008 Bintulu, Sarawak, Malaysia \\ ${ }^{7}$ Institute of Ecosystem Science Borneo, Faculty of Agriculture and Food Sciences, Bintulu Campus Sarawak, Universiti \\ Putra Malaysia, 97008 Bintulu, Sarawak, Malaysia \\ ${ }^{8}$ Department of Integrated Science, School of Secondary Education (Science), Federal College of Education (Technical) \\ Bichi, P.M.B 3473, Kano State, Nigeria
}

(Received on May 20, 2020; Revised on September 26, 2020; Accepted on September 28, 2020)

Essential oils (EOs) have gained a renewed interest in many disciplines such as plant disease control and medicine. This review discusses the components of ginger EOs, their mode of action, and their potential nanotechnology applications in controlling tropical plant diseases. Gas chromatography-mass spectroscopy (GC-MS), high-performance liquid chromatography, and headspace procedures are commonly used to detect and profile their chemical compositions EOs in ginger. The ginger EOs are composed of monoterpenes (trans-

\footnotetext{
*Co-corresponding authors.

Khairulmazmi Ahmad

Phone)+60-126312550

E-mail)khairulmazmi@upm.edu.my

Yasmeen Siddiqui

Phone) +60-0176671219

E-mail)yasmeen@upm.edu.my

(c) This is an Open Access article distributed under the terms of the Creative Commons Attribution Non-Commercial License (http:// creativecommons.org/licenses/by-nc/4.0) which permits unrestricted noncommercial use, distribution, and reproduction in any medium, provided the original work is properly cited.
}

Articles can be freely viewed online at www.ppjonline.org. caryophyllene, camphene, geranial, eucalyptol, and neral) and sesquiterpene hydrocarbons ( $\alpha$-zingiberene, ar-curcumene, $\beta$-bisabolene, and $\beta$-sesquiphellandrene). GC-MS analysis of the EOs revealed many compounds but few compounds were revealed using the headspace approach. The EOs have a wide range of activities against many phytopathogens. EOs mode of action affects both the pathogen cell's external envelope and internal structures. The problems associated with solubility and stability of EOs had prompted the use nanotechnology such as nanoemulsions. The use of nanoemulsion to increase efficiency and supply of EOs to control plant diseases control was discussed in this present paper. The findings of this review paper may accelerate the effective use of ginger EOs in controlling tropical plant diseases.

Keywords : antimicrobial, ginger essential oils, nanotechnology, topical plant diseases

Handling Editor : Jeum Kyu Hong 
In spite of the technological advances in modern agriculture, it remains difficult to control plant diseases in tropical regions because of the limited capacity of chemical products (bactericides, fungicides, among others) to controls diseases without some negative effects (Ghormade et al., 2011; Nega, 2014). In the tropics, the accessibility of effective yet harmful chemicals for controlling plant diseases is scarce (Bajpai et al., 2011; Panth et al., 2020). Moreover, antibiotics and copper based products which are used in plant disease control have adverse effects on human, animal, and environmental health (Hajano et al., 2012; Sundin et al., 2016). The use of antibiotics in controlling plant diseases in many countries have been banned (Buttimer et al., 2017; Pal and Gardener, 2006). Plant disease control often needs expensive and complex integrated pest control approaches to some degree, including environmental management options, the use of unrestricted-pathways and disinfecting approaches (Dara, 2019). Therefore, these limitations affects the control effectively of plant diseases in agriculture (Mcmanus et al., 2002).

Sustainable food production is the key to ensuring food security. Implementation of creative disease management program to reduce the incidence of plant diseases and pathogen resistance is one of the important strategies worth pursuing to achieve this goal. Planning and implementing successful strategies for disease management is necessary to guarantee sustainable crop production systems (Saha et al., 2016). Tropical plants disease outbreak had threatened the ecosystems and agricultural crops which had forced research community to find innovative ways in inhibiting pathogen growth while maintaining crop yield, quality and health status. The use of natural plant products such as ginger essential oils (EOs) is an ideal approach for plant protection in the tropics. In recent times, plant natural products are used not only because of their biological and antimicrobial activities to counter plant diseases (Abdel-Kader et al., 2015) but also for their economic viability and low toxicity (Brusotti et al., 2014). Moreover, plants are well known for their antibacterial, antiviral, antifungal properties, and insect repelling properties (Kumari et al., 2014; Nour et al., 2017; Sendanayake et al., 2017). Possible applications of ginger EOs and their components to control plant diseases in the tropics are being intensified because they are showing promising results both in laboratory and field conditions (Lanzotti et al., 2013; Popović et al., 2016).

Ginger EOs have phytoconstituents such as monoterpene and sesquiterpene hydrocarbons (Dhanik et al., 2017). Analytical methods such as gas chromatography-mass spectroscopy (GC-MS) and headspace chromatography can be used to identify bioactive compounds in ginger EOs (Koch et al., 2017; Marriott et al., 2001). This approach will enable identification and outlining EOs components to assist in achieving the objectives of identifying those compounds responsible for antimicrobial efficacy (Bhattarai et al., 2018; López et al., 2017). The EOs have demonstrated excellent antimicrobial activity against pathogenic microorganisms (Debbarma et al., 2013; Mostafa, 2018; Nikolic et al., 2014; Wonni et al., 2016). However, because of their low water solubility and high sensitivity to oxygen, moisture, heat, and light, so that the use of EOs is limited. The emergence of advanced technologies is making it possible to fix the aforementioned problems associated with EOs use in tropical disease management. The ginger EOs nanobased delivery systems such as nanoemulsions is one of the models for enclosure of these natural bioactive compounds to enhance antimicrobial activity, thus, it can bring active compounds to the desired site, shield them from adverse environmental factors to increase their effectiveness (Donsi and Ferrari, 2016). The mechanisms of action of ginger EOs/ginger EOs nano-based product can affect cells' external package and internal structures. The most likely result of the antimicrobial action is a blend of activities with different targets within a cell. The hydrophobic nature of EOs/EOs nano-based product might be responsible for the destruction of a cell structure resulting in increased permeability because of the cell inability to distinguish the EOs from the cell membrane components (Nazzaro et al., 2013).

Consequently, in order to deal with old and new emerging plant diseases and other threats to crop production, farmers and researchers need to be well versed in the use of natural products such as nanotechnology-based ginger EOs. Efficient and viable plant protection measures using nanotechnology-based ginger EOs are important for society's economic, environmental and social well-being. Increased in crop yields can be related to good plant disease management, including a deeper understanding of natural compounds (ginger EOs) and their use as an efficient way to combat tropical plant diseases. This paper discusses the importance of ginger EOs, EOs-nanotechnology and phytochemical components as antimicrobial active agents as well as their potential applications in controlling plant diseases in the tropical regions. The mechanisms of action of ginger EOs are also discussed.

\section{EOs and Phytochemistry}

Ginger's distinctive constituents are fragrant and pungent types. The fragrant part is commonly referred to as EOs. EOs are semi-oily yellowish volatile aromatic liquids that 
are derived from plant materials such as leaves, flowers, fruits, stems, roots, and seeds through steam/hydro distillation (Böhme et al., 2014). They are biosynthesized from plants and plants' secondary metabolites (Fitriady et al.,
2017), which are usually found in unique cells or organized cells (Nirmala and Nagarajan, 2017). EOs have multiple functions in plants of which they are found to be a part of the plant's defense mechanisms. In ginger EOs, many

Table 1. Chemical compounds in domestic ginger (Zingiber officinale) essential oils

\begin{tabular}{|c|c|c|c|c|c|}
\hline S/No. & Chemical components & RT & Range of conc. (\%) & Formula & Reference \\
\hline 1 & Heptan-2-ol & 6.874 & $1.0-2.0$ & $\mathrm{C}_{7} \mathrm{H}_{16} \mathrm{O}$ & Höferl et al. (2015) \\
\hline 2 & $\alpha$-Pinene & 8.084 & $2.1-3.0$ & $\mathrm{C}_{10} \mathrm{H}_{16}$ & Emmanuel et al. (2013) \\
\hline 3 & Camphene & 8.635 & $5-11.5$ & $\mathrm{C}_{10} \mathrm{H}_{16}$ & Emmanuel et al. (2013) \\
\hline 4 & $\beta$-Pinene & 9.675 & $0.4-1.0$ & $\mathrm{C}_{10} \mathrm{H}_{16}$ & Höferl et al. (2015) \\
\hline 5 & 6-Methyl-5-hepten-2-one & 10.023 & $0.3-0.6$ & $\mathrm{C}_{8} \mathrm{H}_{14} \mathrm{O}$ & Höferl et al. (2015) \\
\hline 6 & Myrcene & 10.228 & $1.8-2.0$ & $\mathrm{C}_{10} \mathrm{H}_{16}$ & Emmanuel et al. (2013) \\
\hline 7 & $\alpha$-Phellandrene & 10.771 & 0.2967 & $\mathrm{C}_{10} \mathrm{H}_{16}$ & Höferl et al. (2015) \\
\hline 8 & $\beta$-Phellandrene & 11.861 & $4.9-5.5$ & $\mathrm{C}_{10} \mathrm{H}_{16}$ & Höferl et al. (2015) \\
\hline 9 & Eucalyptol & 11.941 & $5.0-5.5$ & $\mathrm{C}_{10} \mathrm{H}_{18} \mathrm{O}$ & Sharma et al. (2016) \\
\hline 10 & Terpinolene & 14.474 & $0.2-0.5$ & $\mathrm{C}_{10} \mathrm{H}_{16}$ & Mahdavi et al. (2018) \\
\hline 11 & Methyl lavender ketone & 14.607 & $0.2-0.5$ & $\mathrm{C}_{10} \mathrm{H}_{20} \mathrm{O}_{2}$ & Emmanuel et al. (2013) \\
\hline 12 & 1,6-Octadien-3-ol,3,7-dimethyl & 15.011 & $0.5-1.0$ & $\mathrm{C}_{10} \mathrm{H}_{18} \mathrm{O}$ & López et al. (2017) \\
\hline 13 & Citronellal & 17.474 & $0.5-1.0$ & $\mathrm{C}_{10} \mathrm{H}_{18} \mathrm{O}$ & Höferl et al. (2015) \\
\hline 14 & Isogeranial & 18.024 & $0.4-0.5$ & $\mathrm{C}_{10} \mathrm{H}_{16} \mathrm{O}$ & Höferl et al. (2015) \\
\hline 15 & Borneol & 18.111 & $0.8-1.0$ & $\mathrm{C}_{10} \mathrm{H}_{18} \mathrm{O}$ & Mahdavi et al. (2018) \\
\hline 16 & cis-Verbenol & 18.88 & $0.6-1.0$ & $\mathrm{C}_{10} \mathrm{H}_{16} \mathrm{O}$ & Mahdavi et al. (2018) \\
\hline 17 & Linalyl propionate & 19.298 & $1.0-1.5$ & $\mathrm{C}_{13} \mathrm{H}_{22} \mathrm{O}_{2}$ & Mahdavi et al. (2018) \\
\hline 18 & Citronellol & 21.128 & $0.9-1.0$ & $\mathrm{C}_{10} \mathrm{H}_{20} \mathrm{O}$ & Emmanuel et al. (2013) \\
\hline 19 & Neral & 21.761 & $5.3-10.5$ & $\mathrm{C}_{10} \mathrm{H}_{16} \mathrm{O}$ & Emmanuel et al. (2013) \\
\hline 20 & Geraniol & 22.328 & 0.43753 & $\mathrm{C}_{10} \mathrm{H}_{18} \mathrm{O}$ & Höferl et al. (2015) \\
\hline 21 & Geranial & 23.183 & $7.8-13.8$ & $\mathrm{C}_{10} \mathrm{H}_{16} \mathrm{O}$ & Emmanuel et al. (2013) \\
\hline 22 & 2-Undecanone & 24.112 & $0.6-0.9$ & $\mathrm{C}_{11} \mathrm{H}_{22} \mathrm{O}$ & Mahdavi et al. (2018) \\
\hline 23 & $\alpha$-Copaene & 27.944 & $0.3-0.5$ & $\mathrm{C}_{15} \mathrm{H}_{24}$ & Mahdavi et al. (2018) \\
\hline 24 & Geranyl acetate & 28.196 & $0.2-0.5$ & $\mathrm{C}_{12} \mathrm{H}_{20} \mathrm{O}_{2}$ & Sharma et al. (2016) \\
\hline 25 & $\beta$-Elemene & 28.665 & $0.7-1.0$ & $\mathrm{C}_{15} \mathrm{H}_{24}$ & López et al. (2017) \\
\hline 26 & $\gamma$-Elemene & 30.477 & $0.2-0.5$ & $\mathrm{C}_{15} \mathrm{H}_{24}$ & Mahdavi et al. (2018) \\
\hline 27 & trans- $\beta$-Farnesene & 31.452 & $0.4-1.0$ & $\mathrm{C}_{15} \mathrm{H}_{24}$ & López et al. (2017) \\
\hline 28 & Aromadendrene & 31.701 & $0.2-0.4$ & $\mathrm{C}_{15} \mathrm{H}_{24}$ & Mahdavi et al. (2018) \\
\hline 29 & $\alpha$-Selinene & 32.323 & $0.2-0.3$ & $\mathrm{C}_{15} \mathrm{H}_{24}$ & Sharma et al. (2016) \\
\hline 30 & $\alpha$-Curcumene & 32.613 & $4.4-11.5$ & $\mathrm{C}_{15} \mathrm{H}_{22}$ & Mahdavi et al. (2018) \\
\hline 31 & Eremophilene & 32.739 & $0.2-0.4$ & $\mathrm{C}_{15} \mathrm{H}_{24}$ & Mahdavi et al. (2018) \\
\hline 32 & $\alpha$-Zingiberene & 33.264 & $18.0-28.0$ & $\mathrm{C}_{15} \mathrm{H}_{24}$ & Emmanuel et al. (2013) \\
\hline 33 & Trans-Caryophyllene & 33.728 & $9.0-10.8$ & $\mathrm{C}_{15} \mathrm{H}_{24}$ & Emmanuel et al. (2013) \\
\hline 34 & $\gamma$-Amorphene & 33.927 & $0.3-0.6$ & $\mathrm{C}_{15} \mathrm{H}_{24}$ & Mahdavi et al. (2018) \\
\hline 35 & $\alpha$-Panasinsene & 34.183 & $0.1-0.2$ & $\mathrm{C}_{15} \mathrm{H}_{24}$ & Sharma et al. (2016) \\
\hline 36 & $\beta$-Sesquiphellandrene & 34.42 & $6.5-11$ & $\mathrm{C}_{15} \mathrm{H}_{24}$ & Höferl et al. (2015) \\
\hline 37 & Elemol & 35.414 & $0.5-0.8$ & $\mathrm{C}_{15} \mathrm{H}_{26} \mathrm{O}$ & López et al. (2017) \\
\hline 38 & Germacrene B & 35.788 & $0.3-0.5$ & $\mathrm{C}_{15} \mathrm{H}_{24}$ & Mahdavi et al. (2018) \\
\hline 39 & (E, E)-Farnesol & 35.933 & $0.5-1.9$ & $\mathrm{C}_{15} \mathrm{H}_{26} \mathrm{O}$ & Höferl et al. (2015) \\
\hline 40 & Levomenol & 38.005 & $0.5-0.9$ & $\mathrm{C}_{15} \mathrm{H}_{26} \mathrm{O}$ & Bhattarai et al. (2018) \\
\hline 41 & $\gamma$-Eudesmol & 38.323 & $0.1-0.5$ & $\mathrm{C}_{15} \mathrm{H}_{26} \mathrm{O}$ & Mahdavi et al. (2018) \\
\hline 42 & Zingiberenol & 38.669 & $0.7-1.5$ & $\mathrm{C}_{15} \mathrm{H}_{26} \mathrm{O}$ & Höferl et al. (2015) \\
\hline
\end{tabular}

RT, retention time; Conc., concentrations. 
Table 2. Chemical compounds in wild ginger (Etlingera coccinea) essential oils

\begin{tabular}{|c|c|c|c|c|c|}
\hline S/No. & Chemical components & RT & Range of conc. $(\%)$ & Formula & Reference \\
\hline 1 & Heptan-2-ol & 6.879 & $0.3-0.5$ & $\mathrm{C}_{7} \mathrm{H}_{16} \mathrm{O}$ & Trimanto and Hapsari (2018) \\
\hline 2 & $\alpha$-Pipene & 8.08 & $0.7-0.9$ & $\mathrm{C}_{10} \mathrm{H}_{16}$ & Chiang et al. (2010) \\
\hline 3 & Camphene & 8.616 & $2.4-3.8$ & $\mathrm{C}_{10} \mathrm{H}_{16}$ & Chiang et al. (2010) \\
\hline 4 & $\beta$-Pinene & 9.677 & $1.8-2.7$ & $\mathrm{C}_{10} \mathrm{H}_{16}$ & Jaafar et al. (2007) \\
\hline 5 & $\beta$-Phellandrene & 11.813 & $0.5-1.0$ & $\mathrm{C}_{8} \mathrm{H}_{14} \mathrm{O}$ & Chiang et al. (2010) \\
\hline 6 & Eucalyptol & 11.904 & $1.4-3.6$ & $\mathrm{C}_{10} \mathrm{H}_{18} \mathrm{O}$ & Chiang et al. (2010) \\
\hline 7 & Borneol & 18.106 & $0.6-1.8$ & $\mathrm{C}_{10} \mathrm{H}_{18} \mathrm{O}$ & Trimanto and Hapsari (2018) \\
\hline 8 & 4-Terpineol & 18.651 & $0.7-0.9$ & $\mathrm{C}_{10} \mathrm{H}_{18} \mathrm{O}$ & Chiang et al. (2010) \\
\hline 9 & $\alpha$-Terpineol & 19.284 & $0.9-2.0$ & $\mathrm{C}_{10} \mathrm{H}_{18} \mathrm{O}$ & Trimanto and Hapsari (2018) \\
\hline 10 & Fenchyl acetate & 20.683 & $1.6-4.0$ & $\mathrm{C}_{12} \mathrm{H}_{20} \mathrm{O}_{2}$ & Trimanto and Hapsari (2018) \\
\hline 11 & Neral & 21.63 & $0.8-1.8$ & $\mathrm{C}_{10} \mathrm{H}_{16} \mathrm{O}$ & Chiang et al. (2010) \\
\hline 12 & Geranial & 23.02 & $1.1-2.0$ & $\mathrm{C}_{10} \mathrm{H}_{16} \mathrm{O}$ & Chiang et al. (2010) \\
\hline 13 & Anethole & 23.755 & $1.4-4.6$ & $\mathrm{C}_{10} \mathrm{H}_{12} \mathrm{O}$ & Trimanto and Hapsari (2018) \\
\hline 14 & $\beta$-Elemene & 28.664 & $0.6-3.6$ & $\mathrm{C}_{15} \mathrm{H}_{24}$ & Chiang et al. (2010) \\
\hline 15 & Cyperene & 29.033 & $0.9-1.7$ & $\mathrm{C}_{15} \mathrm{H}_{24}$ & Trimanto and Hapsari (2018) \\
\hline 16 & Methyleugenol & 29.14 & $1.0-2.3$ & $\mathrm{C}_{11} \mathrm{H}_{14} \mathrm{O}_{2}$ & Jaafar et al. (2007) \\
\hline 17 & $\alpha$-Bergamotene & 29.679 & $0.4-1.8$ & $\mathrm{C}_{15} \mathrm{H}_{24}$ & Trimanto and Hapsari (2018) \\
\hline 18 & Caryophyllene & 29.913 & $4.3-6.7$ & $\mathrm{C}_{15} \mathrm{H}_{24}$ & Chiang et al. (2010) \\
\hline 19 & $\alpha$-Humulene & 31.39 & $1.7-3.8$ & $\mathrm{C}_{15} \mathrm{H}_{24}$ & Chiang et al. (2010) \\
\hline 20 & Alloaromadendrene & 31.71 & $1.4-2.6$ & $\mathrm{C}_{15} \mathrm{H}_{24}$ & Joseph et al. (2001) \\
\hline 21 & Selina-4(14),11-diene & 32.305 & $0.6-0.8$ & $\mathrm{C}_{15} \mathrm{H}_{24}$ & Trimanto and Hapsari (2018) \\
\hline 22 & $\alpha$-Curcumene & 32.583 & $1.5-3.5$ & $\mathrm{C}_{15} \mathrm{H}_{22}$ & Chiang et al. (2010) \\
\hline 23 & $\beta$-Chamigrene & 32.713 & $0.7-0.9$ & $\mathrm{C}_{15} \mathrm{H}_{24}$ & Jaafar et al. (2007) \\
\hline 24 & $\beta$-Humulene & 32.802 & $0.8-1.2$ & $\mathrm{C}_{15} \mathrm{H}_{24}$ & Trimanto and Hapsari (2018) \\
\hline 25 & E-Methyl isoeugenol & 33.286 & $37.7-42.2$ & $\mathrm{C}_{11} \mathrm{H}_{14} \mathrm{O}_{2}$ & Chiang et al. (2010) \\
\hline 26 & (Z)- $\alpha$-Bisabolene & 33.456 & $0.6-1.0$ & $\mathrm{C}_{15} \mathrm{H}_{24}$ & Trimanto and Hapsari (2018) \\
\hline 27 & $\beta$-Bisabolene & 33.684 & $1.5-5.2$ & $\mathrm{C}_{15} \mathrm{H}_{24}$ & Chiang et al. (2010) \\
\hline 28 & (Z)- $\gamma$-Bisabolene & 34.014 & $0.5-1.5$ & $\mathrm{C}_{15} \mathrm{H}_{24}$ & Jaafar et al. (2007) \\
\hline 29 & 3,7(11)-Eudesmadiene & 34.148 & $0.4-0.5$ & $\mathrm{C}_{15} \mathrm{H}_{24}$ & Chiang et al. (2010) \\
\hline 30 & $\beta$-Sesquiphellandrene & 34.352 & $2.4-3.8$ & $\mathrm{C}_{15} \mathrm{H}_{22}$ & Trimanto and Hapsari (2018) \\
\hline 31 & (E)- $\gamma$-Bisabolene & 34.681 & $0.3-0.9$ & $\mathrm{C}_{15} \mathrm{H}_{24}$ & Jaafar et al. (2007) \\
\hline 32 & trans-Nerolidol & 35.935 & $0.5-0.8$ & $\mathrm{C}_{15} \mathrm{H}_{26} \mathrm{O}$ & Jaafar et al. (2007) \\
\hline 33 & Spathulenol & 36.613 & $0.6-1.4$ & $\mathrm{C}_{15} \mathrm{H}_{24} \mathrm{O}$ & Jaafar et al. (2007) \\
\hline 34 & Globulol & 36.86 & $1.9-3.8$ & $\mathrm{C}_{15} \mathrm{H}_{26} \mathrm{O}$ & Chiang et al. (2010) \\
\hline 35 & Viridiflorol & 37.21 & $0.7-0.9$ & $\mathrm{C}_{15} \mathrm{H}_{26} \mathrm{O}$ & Joseph et al. (2001) \\
\hline 36 & Guaiol & 37.415 & $1.2-2.0$ & $\mathrm{C}_{15} \mathrm{H}_{26} \mathrm{O}$ & Jaafar et al. (2007) \\
\hline 37 & Ledol & 37.652 & $0.4-1.0$ & $\mathrm{C}_{15} \mathrm{H}_{26} \mathrm{O}$ & Jaafar et al. (2007) \\
\hline 38 & Humulene epoxide II & 37.897 & $0.2-0.5$ & $\mathrm{C}_{15} \mathrm{H}_{24} \mathrm{O}$ & Trimanto and Hapsari (2018) \\
\hline 39 & Spathulenol & 39.025 & $0.5-1.6$ & $\mathrm{C}_{15} \mathrm{H}_{24} \mathrm{O}$ & Jaafar et al. (2007) \\
\hline 40 & Isoelemicin & 39.444 & $0.3-2.0$ & $\mathrm{C}_{12} \mathrm{H}_{16} \mathrm{O}_{3}$ & Joseph et al. (2001) \\
\hline 41 & Intermedeol & 39.683 & $0.9-2.0$ & $\mathrm{C}_{15} \mathrm{H}_{26} \mathrm{O}$ & Jaafar et al. (2007) \\
\hline 42 & Juniper camphor & 39.856 & $0.7-3.6$ & $\mathrm{C}_{15} \mathrm{H}_{26} \mathrm{O}$ & Jaafar et al. (2007) \\
\hline 43 & $\beta$-Bisabolol & 40.198 & $1.9-4.0$ & $\mathrm{C}_{15} \mathrm{H}_{24} \mathrm{O}$ & Chiang et al. (2010) \\
\hline 44 & 1-Chlorooctadecane & 41.279 & $0.4-1.2$ & $\mathrm{C}_{18} \mathrm{H}_{37} \mathrm{cl}$ & Trimanto and Hapsari (2018) \\
\hline 45 & Farnesyl acetate & 46.50 & $1.0-3.0$ & $\mathrm{C}_{17} \mathrm{H}_{28} \mathrm{O}_{2}$ & Chiang et al. (2010) \\
\hline
\end{tabular}

RT, retention time; Conc., concentrations. 
chemical compounds were identified and analyzed for their chemical structure using analytical approaches such as high-performance liquid chromatography, GC-MS (Nour et al., 2017), and headspace (Bylaite et al., 2000). However, there are literature that reported EOs components can be analyzed using gas chromatography but quantifying is done or can be done using spectrophotometer or a combination of these techniques (Ali et al., 2008; Koch et al., 2017). These techniques are commonly used to determine the volatile compounds in ginger EOs. The mass spectrum of the obscured constituents of ginger are commonly identified by comparing their retention times (RT), similarity index, and mass spectral data (Chiang et al., 2010; Trimanto and Hapsari, 2018; Vairappan et al., 2012). In general, RT is useful information for characterizing and distinguishing EOs components (Bhattarai et al., 2018), but they are poorly reproducible over the long term or between different systems and should be relied on only when calculating comparison and sample under the same conditions and shortly after one another. In particular, all factors that could impact RT under otherwise constant conditions could also theoretically affect retention indices. All processes that disrupt or reduce or change the column selectivity of the gas chromatographic separation can cause significant deviations in retention indices (Koo et al., 2014).

The active chemical components in ginger EOs are divided into two major groups, namely, monoterpenes and sesquiterpene hydrocarbons with the general formula of $\left(\mathrm{C}_{5} \mathrm{H}_{8}\right)_{\mathrm{n}}$ and oxygenated hydrocarbon compounds, including aldehydes, phenols, esters, oxide ethers, alcohols, and ketones. Approximately 1,000 monoterpene and 3,000 sesquiterpene hydrocarbons exist. There are other pungent constituents in ginger EOs but in small quantities. Gingerol, shogaol, and paradol, are specific compounds containing sulphur or nitrogen. The chemical components of EOs are similar to those for oils, but differ in their texture, not greasy, and light in weight (El Asbahani et al., 2015). The most abundant chemical compounds in ginger EOs are $\alpha$-zingiberene, geranial, $\alpha$-curcumene, $\beta$-bisabolene, $\beta$-sesquiphellandrene, and neral. These compounds have been related to which most biological activities and distinctive flavor/aroma of EOs. Table 1 shows the presence of

Table 3. Chemical compounds in domestic ginger rhizomes by headspace

\begin{tabular}{|c|c|c|c|c|c|}
\hline S/No. & Chemical components & Rt & Range of conc. $(\%)$ & Formula & Reference \\
\hline 1 & Bisacurone epoxide & 1.773 & $5.6-16.3$ & $\mathrm{C}_{13} \mathrm{H}_{2} \mathrm{O}_{2}$ & Yang et al. (2009) \\
\hline 2 & 2-Heptanone & 5.809 & $0.3-0.9$ & $\mathrm{C}_{7} \mathrm{H}_{14} \mathrm{O}$ & Ruiz et al. (2001) \\
\hline 3 & Heptan-2-ol & 6.015 & $1.6-2.0$ & $\mathrm{C}_{7} \mathrm{H}_{16} \mathrm{O}$ & Huang et al. (2012) \\
\hline 4 & $\alpha$-Pipene & 6.928 & $2.6-5.4$ & $\mathrm{C}_{10} \mathrm{H}_{16}$ & Belliardo et al. (2006) \\
\hline 5 & Camphene & 7.321 & 4.6-16.9 & $\mathrm{C}_{10} \mathrm{H}_{16}$ & Ruiz et al. (2001) \\
\hline 6 & $\beta$-Pinene & 8.055 & $0.9-10$ & $\mathrm{C}_{10} \mathrm{H}_{16}$ & Yang et al. (2009) \\
\hline 7 & Myrcene & 8.359 & $4.0-7.7$ & $\mathrm{C}_{10} \mathrm{H}_{16}$ & Belliardo et al. (2006) \\
\hline 8 & Octanal & 8.663 & $0.4-1.0$ & $\mathrm{C}_{8} \mathrm{H}_{16} \mathrm{O}$ & Ruiz et al. (2001) \\
\hline 9 & $\alpha$-Phellandrene & 8.781 & $0.7-9.8$ & $\mathrm{C}_{10} \mathrm{H}_{16}$ & Yang et al. (2009) \\
\hline 10 & $\beta$-Phellandrene & 9.504 & $4.5-11.6$ & $\mathrm{C}_{10} \mathrm{H}_{16}$ & Belliardo et al. (2006) \\
\hline 11 & Eucalyptol & 9.561 & $5.6-14.9$ & $\mathrm{C}_{10} \mathrm{H}_{18} \mathrm{O}$ & Shao et al. (2003) \\
\hline 12 & Butyl 2-methylvalerate & 9.76 & $0.7-0.9$ & $\mathrm{C}_{10} \mathrm{H}_{18} \mathrm{O}$ & Ruiz et al. (2001) \\
\hline 13 & Linalool & 11.503 & $0.7-2.3$ & $\mathrm{C}_{10} \mathrm{H}_{18} \mathrm{O}$ & Ruiz et al. (2001) \\
\hline 14 & Citronellal & 13.084 & $0.7-1.4$ & $\mathrm{C}_{10} \mathrm{H}_{18} \mathrm{O}$ & Huang et al. (2012) \\
\hline 15 & Neral & 15.717 & $2.8-5.8$ & $\mathrm{C}_{10} \mathrm{H}_{16} \mathrm{O}$ & Huang et al. (2012) \\
\hline 16 & Geranial & 16.564 & $4.1-5.0$ & $\mathrm{C}_{10} \mathrm{H}_{16} \mathrm{O}$ & Yang et al. (2009) \\
\hline 17 & 2-Undecanone & 17.198 & $0.3-0.9$ & $\mathrm{C}_{11} \mathrm{H}_{22} \mathrm{O}$ & Shao et al. (2003) \\
\hline 18 & Copaene & 19.716 & $0.4-1.3$ & $\mathrm{C}_{15} \mathrm{H}_{24}$ & Fan et al. (2018) \\
\hline 19 & $\alpha$-Curcumene & 22.495 & $5.0-6.93$ & $\mathrm{C}_{15} \mathrm{H}_{22}$ & Ruiz et al. (2001) \\
\hline 20 & Germacrene D & 22.591 & $0.5-1.2$ & $\mathrm{C}_{15} \mathrm{H}_{24}$ & Shao et al. (2003) \\
\hline 21 & $\alpha$-Zingiberene & 22.83 & $7.1-20$ & $\mathrm{C}_{15} \mathrm{H}_{24}$ & Yang et al. (2009) \\
\hline 22 & $\alpha$-Farnesene & 23.077 & $2.8-7.9$ & $\mathrm{C}_{15} \mathrm{H}_{24}$ & Belliardo et al. (2006) \\
\hline 23 & $\beta$-Bisabolene & 23.175 & $1.0-1.9$ & $\mathrm{C}_{15} \mathrm{H}_{24}$ & Huang et al. (2012) \\
\hline 24 & $\beta$-Sesquiphellandrene & 23.583 & $2.2-6.5$ & $\mathrm{C}_{15} \mathrm{H}_{24}$ & Huang et al. (2012) \\
\hline
\end{tabular}

RT, retention time; Conc., concentrations. 
monoterpene components such as trans-caryophyllene, camphene, geranial, eucalyptol, and neral as well as sesquiterpene hydrocarbons mainly $\alpha$-zingiberene, ar-curcumene, $\beta$-bisabolene, $\beta$-sesquiphellandrene. The most reported available components with high concentrations (\%) are $\alpha$-zingiberene (18.0-28.0\%), geranial (7.8-13.8\%), neral (5.3-10.5\%), trans-caryophyllene (9.0-10.8\%), eucalyptol $(5.0-5.5 \%), \beta$-phellandrene (4.9-5.5\%), camphene (5$11.5 .0 \%), \alpha$-pinene $(2.1-3.0 \%)$, and heptan-2-ol (1.0$2.0 \%)$. These compounds might be responsible for their distinctive flavor and aroma as well as antibacterial and antifungal activities. Table 2 shows the chemical compounds in wild ginger EOs. Monoterpenes such as camphene, geranial, geranyl acetate, anethole, fenchyl acetate, and neral as well as sesquiterpene hydrocarbons mainly $\alpha$-humulene, $\alpha$-curcumene, $\beta$-bisabolene, and $\beta$-sesquiphellandrene were identified. The most abundant compounds are Emethyl isoeugenol (37.7-42.2\%), caryophyllene (4.3-6.7\%), $\beta$-bisabolene (1.5-5.2\%), anethole (1.4-4.60\%), eucalyptol (1.4-3.6\%), $\beta$-bisabolol (1.9-4.0\%), globulol (1.9-3.8\%), arcurcumene (4.4-11.5\%), $\alpha$-humulene (1.7-3.8\%), fenchyl acetate (1.6-4.0\%), $\beta$-pinene (1.8-2.7\%), alloaromadendrene (1.4-2.6\%), and geranial (7.8-13.8\%) responsible for the distinctive flavor and aroma.

The constituents of ginger EOs are strongly associated with place of origin or geographical location, and also whether the rhizomes are fresh or dried (Koch et al., 2017). Fresh ginger EOs are of higher quality in terms of<smiles>CC(C)=CCCC(C)C1C=CC(C)=CC1</smiles><smiles>CC(C)=CCC/C(C)=C/C=O</smiles><smiles>CC1=CCC(C)C=CC(C)C1</smiles>
$\alpha$-Humulene<smiles>C=C(CCC=C(C)C)C1CC=C(C)CC1</smiles>

$\beta$-Bisabolene<smiles>C=C1C=CC(C(C)C)CC1</smiles>

$\beta$-Phellandrene<smiles>C=C1CC/C=C(/C)CC[C@H]2C[C@H]1C2(C)C</smiles>

$\beta$-Caryophyllene<smiles>CC(C)=CCCC(C)c1ccc(C)cc1</smiles><smiles>C/C=C/c1ccc(O)c(OC)c1</smiles>

Eucalyptol

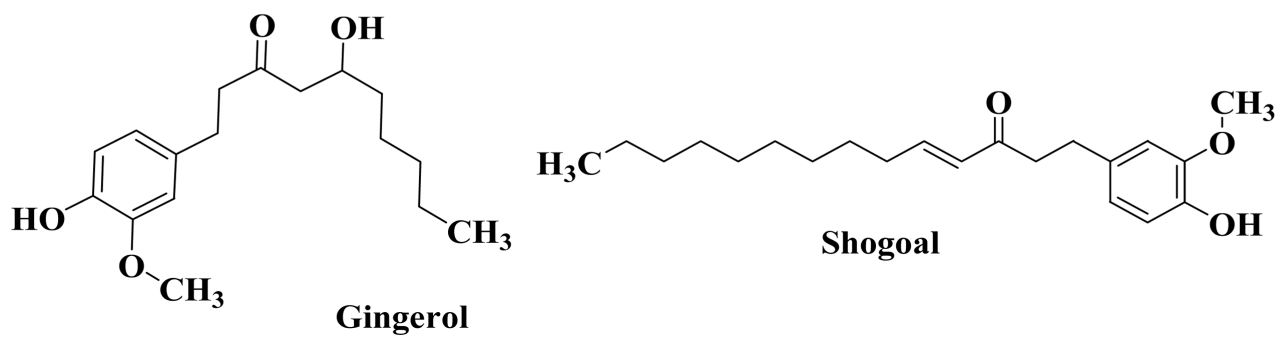

Fig. 1. Some selected chemical structures of components in wild and domestic ginger essential oils. Major bioactive molecules of essential oils (EOs) and their pharmacological activities play an important role in the protection of crops in the tropics, such as antioxidant, antifungal and antibacterial activities. With the associated mechanisms of action, the effect of EOs and the functions of their major components in the tropics as natural preservatives cannot be overemphasized. 
fragrance/flavor than dried ginger, thus receiving more oils and better anti-microbes activity (Mahboubi, 2019; Onyenekwe and Hashimoto, 1999). Similarly, Tables 3 and 4 shows the chemical compounds in domestic and wild ginger by headspace method, they are characterized by monoterpenes such as camphene, geranial, linalool, and neral. The most abundant compounds are sesquiterpene hydrocarbons, mostly $\alpha$-zingiberene, ar-curcumene, $\beta$-bisabolene, $\beta$-sesquiphellandrene, $\beta$-ionone 5,6-epoxide and their $\%$ concentrations are camphene (4.6-16.9\%), $\beta$-ionone 5, 6-epoxide (5.6-16.3\%), eucalyptol (5.6-14.9\%), $\beta$-phellandrene (4.5-11.6\%), $\alpha$-zingiberene (7.1-20\%), $\alpha$-pinene (2.6-5.4\%), geranial (4.1-5.0\%), myrcene (4.0$7.7 \%)$, neral (2.8-5.8\%), $\alpha$-farnesene (2.8-7.9\%), heptan2-ol (1.6-2.0\%), $\beta$-sesquiphellandrene (6.5-11\%), and $\beta$-bisabolene (1.5-5.2\%). These compounds could be associated with the distinctive flavor and aroma of EOs as well as their antibacterial and antifungal activities whereas the wild ginger type is made up of $\beta$-phellandrene (4.2-42.7\%), $\beta$-pinene (17.2-22.0\%), $\alpha$-pinene (2.1-4.2\%), and E-methyl isoeugenol (3.9-37.0\%) as the major constituents (Awang et al., 2011; Bhattarai et al., 2018; López et al., 2017; Mahboubi, 2019; Şener et al., 2017). However, different analysis of natural products yields different efficiencies (Sharifi-Rad et al., 2017b) because of factors such as time for analysis and rhizomes are not efficiently utilized by headspace. In other words, some of the phytoconstituents are hidden in the rhizomes compared to the extracted EOs. Fig. 1 shows selected chemical structures of components in ginger EOs (Mahboubi, 2019). Furthermore, Table 5 shows that ginger possess chemical classes and biological activities such as antibacterial, antifungal, antioxidant, and antiinflammatory activities (Mahboubi, 2019; Mao et al., 2019) because many monoterpene components and sesquiterpene hydrocarbons are known to be the main components of
EOs.

\section{Antimicrobial Activity of Ginger EOs}

The escalating economic and social effects of plant pathogens inevitably suggest that continuous steps are being taken to monitor plant diseases in order to produce nutritious and pesticides-free foods. This can be achieved by developing and adopting natural antimicrobials from plant sources like ginger EOs and these important issues has generated interest amongst scientific community ( $\mathrm{Li}$ et al., 2020). Generally, ginger EOs is non-phytotoxic substances and are possibly efficient against many plant pathogenic microbes. The use of antimicrobial compounds from plant sources such as EOs has been one of the first options following outbreaks of plant diseases in recent years.

The antimicrobial properties ginger EOs had been extensively studied using advanced scientific methods. The evaluation of the antimicrobial activity of EOs is done by testing their effectiveness on living organisms such as bacteria and fungi, which can range from molecular tissue to the whole organism. It is a stage of evaluating the conduct of the EOs on the test species (Gurjar et al., 2012). The potential application of EOs against both bacteria and fungi have been reported mostly in vitro tests. The findings had suggested substantial antimicrobial activities compared with the standard control against many plant pathogens (Al-Hetar et al., 2011; Alzoreky and Nakahara, 2003; Sharma et al., 2016). Such findings suggested that many bacterial and fungal pathogens could be managed effectively by ginger EOs.

Furthermore, earlier in vitro and in vivo studies had indicated that ginger EOs could be used as effective antimicrobial agents for animal diseases. However, data on the antimicrobial activity of ginger EOs against plant bacterial

Table 4. Chemical compounds in wild ginger rhizome by headspace

\begin{tabular}{clclll}
\hline S/No. & Chemical component & RT & Range of conc. (\%) & Formula & Reference \\
\hline 1 & $\alpha$-Pinene & 8.129 & $2.1-4.2$ & $\mathrm{C}_{10} \mathrm{H}_{16}$ & Huang et al. (2012) \\
2 & Camphene & 8.609 & $5.0-11.6$ & $\mathrm{C}_{10} \mathrm{H}_{16}$ & Yang et al. (2009) \\
3 & $\beta$-Pinene & 9.411 & $17.2-22.0$ & $\mathrm{C}_{10} \mathrm{H}_{16}$ & Yang et al. (2009) \\
4 & Myrcene & 9.677 & $0.4-1.9$ & $\mathrm{C}_{10} \mathrm{H}_{16}$ & Sa-nguanpuag et al. (2008) \\
5 & $\beta$-Phellandrene & 9.681 & $4.2-42.7$ & $\mathrm{C}_{8} \mathrm{H}_{14} \mathrm{O}$ & Huang et al. (2012) \\
6 & Eucalyptol & 10.86 & $0.4-1.5$ & $\mathrm{C}_{10} \mathrm{H}_{18} \mathrm{O}$ & Yang et al. (2009) \\
7 & Caryophyllene & 10.937 & $0.4-0.9$ & $\mathrm{C}_{15} \mathrm{H}_{24}$ & Sa-nguanpuag et al. (2008) \\
8 & E-Methyl isoeugenol & 11.276 & $3.9-37.0$ & $\mathrm{C}_{11} \mathrm{H}_{14} \mathrm{O}_{2}$ & Sa-nguanpuag et al. (2008) \\
9 & $\beta$-Bisabolene & 12.900 & $1.0-5.2$ & $\mathrm{C}_{15} \mathrm{H}_{24}$ & Yang et al. (2009) \\
10 & Fenchyl acetate & 22.624 & $4.6-5.6$ & $\mathrm{C}_{12} \mathrm{H}_{20} \mathrm{O}_{2}$ & Yang et al. (2009) \\
\hline
\end{tabular}

RT, retention time; Conc., concentrations. 
Table 5. Ginger essential oils' major chemical classes and biological activity of chemical constituents

\begin{tabular}{|c|c|c|c|c|c|}
\hline Classes & $\begin{array}{l}\text { Functional } \\
\text { groups }\end{array}$ & $\begin{array}{l}\text { Structure } \\
\text { types }\end{array}$ & $\begin{array}{l}\text { Examples of chemical } \\
\text { constituents }\end{array}$ & Biological activities & References \\
\hline \multirow[t]{3}{*}{ Terpenes } & Carbures & Acyclic & Myrcene & Antibacterial & Mesomo et al. (2013) \\
\hline & & $\begin{array}{l}\text { Monocyclic } \\
\text { Bicyclic }\end{array}$ & Phellandrenes, pinenes, camphene & & \\
\hline & Alcohols & $\begin{array}{l}\text { Acyclic } \\
\text { Monocyclic } \\
\text { Bicyclic }\end{array}$ & $\begin{array}{l}\text { Geraniol, linalol, citronellol, etc. } \\
\alpha \text {-Terpineol, carveol, } \\
\text { Borneol, fenchol, chrysanthenol, } \\
\text { thuyan-3-ol }\end{array}$ & $\begin{array}{l}\text { Antibacterial, } \\
\text { antifungal }\end{array}$ & Das et al. (2013) \\
\hline \multirow[t]{6}{*}{ Monoterpenes } & Aldehydes & Acyclic & Geranial, neral, citronellal & $\begin{array}{l}\text { Antibacterial, antifungal, } \\
\text { antioxidant }\end{array}$ & El-Baroty et al. (2010) \\
\hline & Ketone & Acyclic & Tegetone, etc. & NR & \\
\hline & & Monocyclic & $\begin{array}{l}\text { Menthones, carvone, pulegone, } \\
\text { piperitone, etc. }\end{array}$ & & \\
\hline & Esters & $\begin{array}{l}\text { Acyclic } \\
\text { Monocyclic } \\
\text { Bicyclic }\end{array}$ & $\begin{array}{l}\text { Linalyl acetate, citronellyl acetate, etc. } \\
\alpha \text {-terpinyl acetate, etc. } \\
\text { Isobornyl acetate, etc. }\end{array}$ & NR & \\
\hline & Ethers & Bicyclic & 1,8-Cineole etc. & Anti-inflammatory & de Melo et al. (2011) \\
\hline & Phenols & Monocyclic & Thymol, carvacrol, etc. & Antifungal, antibacterial & $\begin{array}{l}\text { Nazzaro et al. (2013, } \\
\text { 2017) }\end{array}$ \\
\hline \multirow[t]{2}{*}{ Sesquiterpenes } & Carbures & $\begin{array}{l}\text { Acyclic } \\
\text { Monocyclic }\end{array}$ & $\begin{array}{l}\text { Farnesenes, etc. } \\
\beta \text {-Bisabolene, zingiberene, curcumenes, } \\
\text { elemenes }\end{array}$ & $\begin{array}{l}\text { Antibacterial, antifungal, } \\
\text { antioxidant }\end{array}$ & El-Baroty et al. (2010) \\
\hline & Alcohols & $\begin{array}{l}\text { Acyclic } \\
\text { Monocyclic }\end{array}$ & $\begin{array}{l}\beta \text {-Nerolidol, farnesol, etc. } \\
\text { Bisabolol, etc. }\end{array}$ & Antibacterial, antifungal & $\begin{array}{l}\text { Sasidharan and Menon } \\
\text { (2010) }\end{array}$ \\
\hline
\end{tabular}

NR, no report.

and fungal pathogens are very minimal. Nevertheless, because of the biologically active compounds present in ginger EOs are known to be antibacterial and antifungal bioagents, thus the research interest on testing for controlling plant diseases are increasing. Many studies revealed that the characteristics of the oils contributing to the respective antimicrobial activity depend on the nature of the plant volatile oils, the structural arrangement of the components, and their functional groups or potential synergistic interactions between the components. The correlation between the antimicrobial activity of the compounds and their relative percentage composition in the plant volatile oils with their chemical structure, functional groups, and configuration, indicates their bioactivity (Dorman and Deans, 2000).

In field experiments, the antimicrobial properties of ginger EOs with non-toxic features can be used to evaluate disease control efficacy on tropical plant diseases such as fusarium wilt of banana (Fusarium oxysporum f. sp. cubense), papaya dieback (Erwinia mallotivora), and basal stem rot of oil palm (Ganoderma boninense). The effects of EOs on tropical field crops are distinct from those of the conventional pesticides. Nonetheless, in comparison to the EOs, the test outputs of chemical pesticides may demonstrate in higher degree of effectiveness. However, other report revealed that EOs play a key role on various crops production as assessed by the integrated pest management program (IPM), in which specific approaches work in a synergistic manner for high yield and quality product (Bhavaniramya et al., 2019). Therefore, intensive open field experiments are needed to uncover the mechanisms underlying the antimicrobial activity of ginger EOs with their interactions as well as improving their action against the target host through nanoemulsion approach could protect crops against pathogenic microbes.

\section{Possible Mechanisms of Ginger EOs}

It is believed that EOs antimicrobial activity against multiple cell targets of plant pathogens (Wu et al., 2019). Many researchers had used high resolution microscopes such as scanning electron microscopy and transmission electron microscopy to observe morphological changes in 


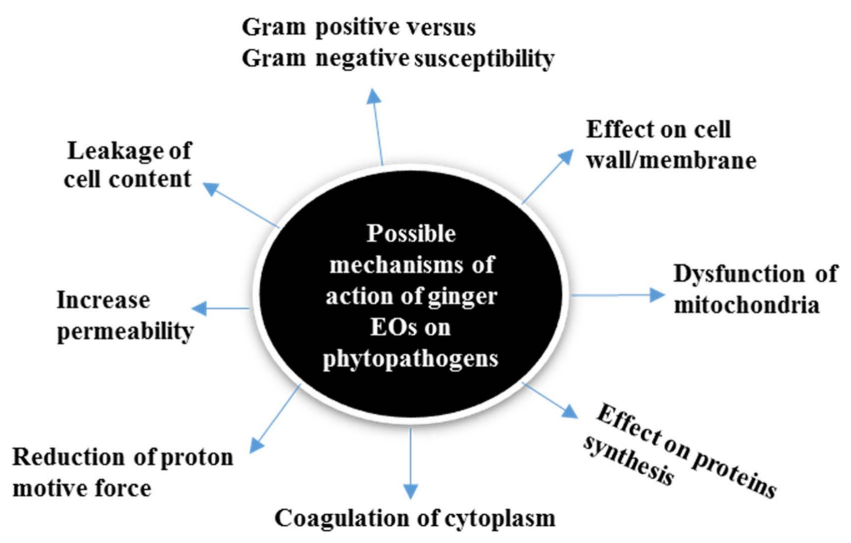

Fig. 2. Roles of ginger essential oils on phytopathogen cells for plant disease control. The essential oils (EOs)' biological properties are closely related to their aromatic compounds. In relation to mechanisms of action, the chemical composition of the EOs and their in vitro phytotoxic activity against phytopathogenic cells play an important role in crop protection in the tropics.

pathogen cells when in contact with EOs (Inkson, 2016; $\mathrm{Wu}$ et al., 2019). The micrographs usually show the cell surface of pathogen cells as not smooth and irregular ( Wu et al., 2019) in suggesting that EOs could deteriorate the cell membrane morphology, dysfunction of mitochondria, and proteins synthesis resulting in multiple clefts, ending in disruption, and lysis of a cell (Sahu et al., 2018). Fig. 2 demonstrates that inhibition of growth and development of phytopathogens by ginger EOs.

Gram-positive and Gram-negative susceptibility. A wide range of in vitro antimicrobial assessment have been used for EOs assays (Arifullah et al., 2014; González Villa and Veiga-Crespo, 2014; Liu et al., 2017; Vasireddy et al., 2018). In terms of susceptibility, Gram-positive bacteria more susceptible to EOs compared with gram-negative bacteria (Dhifi et al., 2016) because is the fact that Gramnegative bacteria are the holders of the outer membrane covering the cell wall of plant pathogenic bacteria. Therefore, offer greater resistance to EOs by preventing easy diffusion through the lipopolysaccharide membrane and preventing their accumulation in the cell (Tao et al., 2019). In addition, the cell of the Gram-negative bacteria is rigid, rich in lipopolysaccharide, and more complex, thus restricting the diffusion of hydrophobic compounds through cell membrane, whereas this extra-complex membrane is absent in Gram-positive bacteria which are only surrounded by a thick peptidoglycan wall, lipophilic ends of lipoteichoic acid in the cell membrane, which is really not sufficiently dense to stop smaller antimicrobial molecules, thus, enabling entry to the cell membrane (López et al., 2017; Nazzaro et al., 2013). A number of reports revealed that the EOs effects are as a result of additive, versatile or antagonistic characteristics of individual components in different amounts (Dhifi et al., 2016; Vasireddy et al., 2018).

Effects of EOs on cell wall/membrane. Hydrophobicity is the most important characteristic that makes the operation of EOs in living cell effective. EOs can partition into the lipids layer of cell membranes as hydrophobic compounds (Sahu et al., 2018). Such action disturbs cell membrane and makes it more permeable, enabling ion and metabolite leakage (Chouhan et al., 2017). Whereas leakage does not result in a loss of cell viability up to a certain point, further leakage may be lethal (for example, bacterial cell membrane) (Tao et al., 2019). In a related study, a decrease in $\mathrm{pH}$ was reported because of the disruption of the cell membrane of plant pathogenic bacteria (Chouhan et al., 2017) suggesting that regulation of cellular processes such as transcription of DNA, protein synthesis, or activation of enzymes were altered (López et al., 2017). The significant

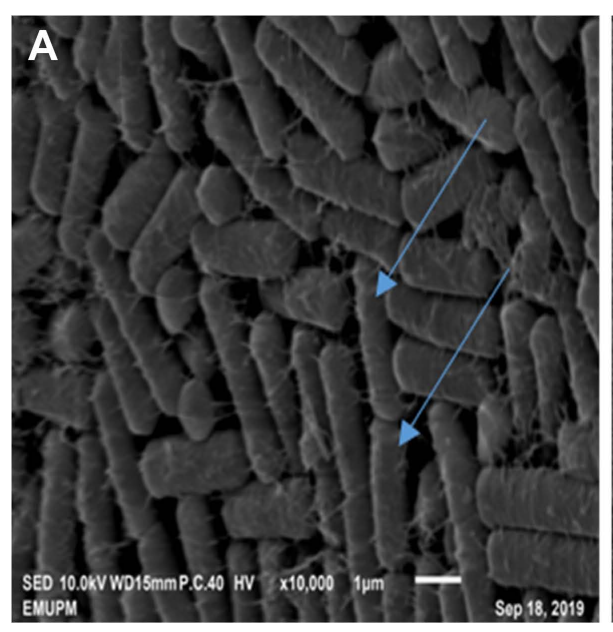

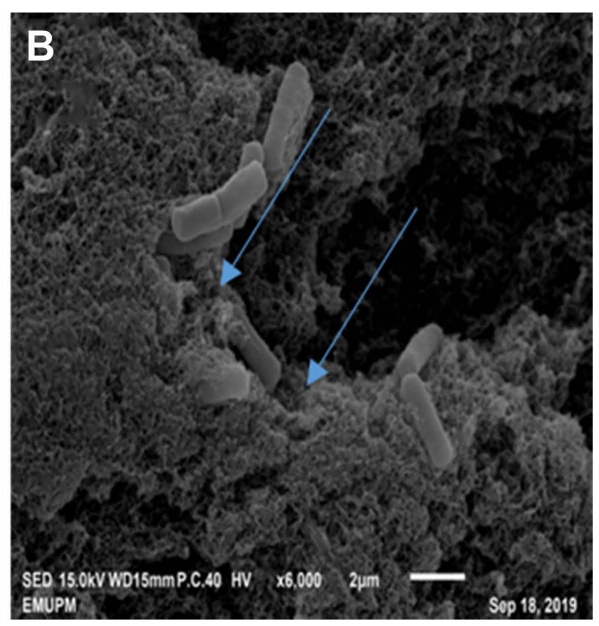

Fig. 3. Transmission electron micrograph showing the effect of ginger essential oils (EOs) on bacterial cells which causes ultrastructural modifications. (A) Cells with a normal rod shape, smooth and bright surface. (B) Cells treated with ginger EOs showing irregular shape with sunken surfaces, severely disruption of the cells, thus, lead to membrane disruption, protein, and mitochondria dysfunctions, DNA damage which lead to inhibition of electron transport chain and metabolic process regulation, and finally cell death. 
feature of EOs and their constituents is their hydrophobicity. This enables them to partition cell walls and part of cells in lipids, disrupting structures, and making them more permeable (Fig. 3). EOs tend to function on cytoplasmic membrane as cell proteins (Dhifi et al., 2016; Lucas et al., 2012). Such action disturbs cellular processes resulting in alteration of protein synthesis. There are two major pathways of the mechanisms of action. The EOs lipophilic molecules that accumulate in the lipid bilayer of the cell interact with lipid-protein to alter the phospholipid bilayer integrity or by interacting with the embedded phospholipid bilayer active transport proteins (Chouhan et al., 2017).

Dysfunction of mitochondria. The principal mechanisms which mediate the cytotoxic effects of EOs are activation of cell death by inducing apoptosis and/or necrosis processes, cell cycle suspension, and the loss of essential organelles (Sharifi-Rad et al., 2017a). Several effects occur because of the lipophilic nature and low molecular weight of the main components made up of EOs which enable them to cross cell membranes, alter membrane composition and changing membranes resulting in lower production of ATP, changes in $\mathrm{pH}$ gradient, and depletion of mitochondrial ability leading to cell death (Dhifi et al., 2016). EOs can damage cytoplasm function by disrupting respirational processes in bacterial cells (Akhtar et al., 2019). Mitochondrial efficacy impeded by suppressing the function of mitochondrial dehydrogenases associated with ATP biosynthesis, such as lactate dehydrogenase, malate dehydrogenase, and succinate dehydrogenase (Nazzaro et al., 2017). Soylu et al. (2006) revealed that EOs from medicinal plants such as oregano (Origanum syriacum var. bevanii (Holmes) Letsw.), thyme (Thymbra spicata L. subsp. spicata), lavender (Lavandula stoechas L. subsp. stoechas), rosemary (Rosmarinus officinalis L.), fennel (Foeniculum vulgare Mill.), and laurel (Laurus nobilis L.) have been screened for late blight disease in tomatoes. The treatment with EOs caused loss of cell wall integrity and eased plasma membrane permeability with major morphological changes in the hyphae of targeted fungal pathogen. Phenolic-rich Lavandula's antifungal function showed that EOs was also capable of acting as an antifungal agent by disrupting the cycle and inhibiting the synthesis of ATP in mitochondria. Mitochondria experienced significant degradation of the internal structure with a reduction in the mitochondrial cristae.

Effects of EOs on virulence factor. EOs affect the virulence factors of microbes by inhibiting bacterial motility through inhibition of flagella formation, destruction of the basic structure of flagella and its synthesis, and degradation of flagella. Flagellin contains a pathogen-related molecular pattern which initiates a cascade for signal transduction. It should be noted that while the degradation of flagella can destroy bacterial motility to decrease the corresponding adhesive and infective abilities, the disappearance of flagella can also cause undesirable changes to the bacteria and lead to death of the bacteria (Zhang et al., 2020).

A significant proportion of signaling systems had been described in plant pathogens, with the major ones being quorum sensing (QS) and signal transduction pathways (Sahu et al., 2018; Zhang et al., 2020). QS is a bacterial communication mechanism often which it used to convey different surviving or virulence traits which result in increased resistance. Thus, bacteria use QS to interact and evaluate cell density by generating small sensing components, termed as auto-inducers. These auto-inducers are detected in the immediate environment by bacteria and influence gene expression when a critical limit is reached. The mechanisms identified to clarify the anti-QS action of EOs include inhibiting the production of QS signaling molecules and inactivating of cognate receptors, which in effect inactivate the expression of virulence genes required for cohesiveness. Generating and storing signal molecules is the prerequisite for activating the QS system so that it is able to inhibit the output of signals (Poli et al., 2018; Zhang et al., 2020). The variability of EOs anti-QS ability is related to their diverse chemical constituents, such as $\alpha$-zingiberene, ar-curcumene, $\beta$-bisabolene, and eucalyptol which tend to be more efficient for QS inhibition (Asfour, 2018). Hence, the discovery of unique hyperactivity/impulsivity and secure QS inhibition from EOs is of great importance for better control of phytopathogens (Kerekes et al., 2013; Tariq et al., 2019).

Action of EOs on reactive oxygen species (ROS) and Fenton reaction (FR). ROS and FR are general terms used to signify molecules and reactive intermediates that have a highly positive redox potential in living organisms' cells (Vatansever et al., 2013). They can assault a number of targets for antimicrobial activity, which is responsible for their flexibility in host mediation against a large array of pathogens (Winterbourn, 2008). EOs were found to produce ROS and FR during antimicrobial activities in their mode of action due to their structural components, which play a role in inducing oxidative stress and destroying the microbial cells (Nazzaro et al., 2017).

ROS are generated constantly as naturally occurring substances of certain biological processes and under delicate control and at the same time, some related or non-specific processes catalyze the ROS reactions. Two different pro- 
cesses occur, the production and elimination of ROS that are usually controlled by fine cellular mechanisms. Many a times the stable ROS level is present in the cells by the absence of antimicrobial agents (Winterbourn, 2008). However, under certain conditions or with the presence of biopecticides (e.g., EOs) will resulted in increased in cell concentration, called oxidative stress, and disturbs the equilibrium between ROS generation and degradation, thus destroying the microbial cells. ROS serve as an alternative mechanism for the test of bactericides (Memar et al., 2018).

Oxidative stress is basically the disparity amongst cellular respiration and metabolism generating ROS, and the ability of cells to neutralize the harmful effects (Jugreet et al., 2020). ROS consists of radical and non-radical oxygen species such as superoxide anion $\left(\mathrm{O}_{2}^{-}\right)$, hydrogen peroxide $\left(\mathrm{H}_{2} \mathrm{O}_{2}\right)$, hydroxyl ion $\left(\mathrm{OH}^{-}\right)$, hydroxyl radical $(\mathrm{OH})$, peroxide $\left(\mathrm{O}_{2}{ }^{2-}\right)$, and singlet oxygen $\left(\mathrm{O}^{2}\right)$; these usually affect cell components such as lipids, proteins and nucleic acid (Dwyer et al., 2009). Oxidative damage is a self-propagating chain reaction involving reactions between ROS and the cellular components in the membrane (Memar et al., 2018) by the presence of antimicrobials (EOs) due to their component of monoterpenes and sesquiterpenes hydrocarbons (Nazzaro et al., 2017). Obviously, the encounter between a thriving microbial community and antimicrobials molecules (EOs) that threaten the life of this community and poses huge stress to any microbe in the environment. The critical effect of this stress caused by biopecticides is to create an intracellular environment that is highly conducive to genetic evolution due to a tremendous degree of selective pressure and the microbe's physiological responses. Such reaction will cause membrane damage at the cellular level, and eventually kill the cell. Covalent modification also results in contact between ROS and proteins/lipids, which typically destabilizes and inactivates a specific protein/lipids (Ezraty et al., 2017). Nucleic acid is also a prime target for ROS; oxidizing nucleotides like guanine, causing lesion, and breaking the DNA. This results in the production of non-functional proteins which ultimately kill the cells (Memar et al., 2018). The high ROS concentrations generated, the more effect on cellular membranes which eventually resulted in death of cells.

However, according to some researches, phenolic compounds (Gingerols, Shogaols, Zingerone, etc.) and their synergistic volatile compounds such as $\alpha$-zingiberene, cis-caryophillene, $\alpha$-farnesene, $\beta$-bisabolene, and $\beta$-sesquiphellandrene contained in ginger essential oil are primarily responsible for the antimicrobial activity; thus, antibacterial activity of ROS generated and mediated by
EOs are as a result of these compounds. The investigations revealed that EOs compounds can disrupted the cellular plasma membrane (Jugreet et al., 2020), resulting in altered membrane potential as well as $\mathrm{pH}$ gradient and intracellular ATP levels (Nazzaro et al., 2017). The DNA damage was also observed with the generation of ROS in terpene catechol treated bacteria (Memar et al., 2018). The process disrupt protein synthesis, produce large amounts of hydroxyl radicals with misquotation and mutation of proteins (Dwyer et al., 2009). So, the ROS inducer may soon serve as a potential treatment modality in combating resistant pathogens.

Similarly, FR is an important antibacterial mode of action of EOs. This reaction produces hydroxyl radicals $\left({ }^{\circ} \mathrm{OH}\right)$ which are highly reactive and toxic. Hydroxyl radicals oxidize lipids, causing oxidative damage that induces hydrophobic phospholipids in the membrane, and increases membrane fluidity, resulting in abnormalities, damage to the membrane structure and function. Furthermore, according to some findings, ferrous ion $\left(\mathrm{Fe}^{2+}\right)$ is capable of binding to biomolecules, and $\mathrm{OH}^{-}$formation can occur in the immediate vicinity of DNA, proteins, and lipids, causing its detrimental effect (Memar et al., 2018). $\mathrm{Fe}^{2+}$ displays a sequence-specific affinity when communicating with DNA and leads to the FR in which ${ }^{\circ} \mathrm{OH}$ production causes much of the damage. Hence, more covalently bonded iron is involved in the Fenton oxidation reaction, leading to the formation of ${ }^{\circ} \mathrm{OH}$ and bacterial death. However, gene expression related to proton transportation in the cell will decreased by the presence of $\mathrm{Fe}^{2+}$. ATP synthesis coupled proton transport can all affect the synthesis of ATP necessary for intracellular protons to be transported outside the cell. Decreased expression of these genes increases the ferrous concentration by reducing the transport of extracellular protons and decreasing intracellular $\mathrm{pH}$, resulting in damage to the cell membrane and cell death (Memar et al., 2018). The work of Lee et al. (2020) on EOs against Agrobacterium tumefaciens revealed that trans-cinnamaldehyde and salicylaldehyde antibacterial mode of action is ROS generation by FR triggered the down-regulation of the ATP synthesis-related gene sequence, degraded iron ion homeostasis and corrupted ROS protection mechanism. EOs induce ROS as a principal mechanism of antibacterial effect. It has a different approach to killing ROS and FR-induced microbial cells which eventually disrupts the membrane and kills the cell. This will make EOs as a promising bioagent that would promote natural antimicrobials for the control of tropical plant diseases. 


\section{Potential of Ginger EOs to Control Plant Diseases} in the Tropics

Tropical crops face major yield losses due to insect pests and plant diseases. One of the main drawbacks of disease control approaches is the environmental factor. In the tropics, the environment is highly conducive for proliferation of many plant pathogens all year round. Moreover, the efficacy of the existing synthetic chemicals is limited in the field due to their adverse environmental effects (Bajpai et al., 2011). Thus, there is an immediate need for identifying suitable alternative for fungicidal and bactericidal compounds from plant (Lee et al., 2016). Historically, ginger extracts and ginger EOs possess medicinal properties and antimicrobial activities (Jakribettu et al., 2016) which offer an options for plant disease management in the tropical regions (Gurjar et al., 2012). Numerous studies have shown that ginger EOs is effective against multi-resistant bacteria and fungi (Nikolic et al., 2014). Moreover, ginger EOs have been tested for their potency in the field against bacterial blight pathogen (Rajip et al., 2016).

In agriculture, EOs have been successfully tested as a natural disease control technique for managing the growth of harmful phytopathogens (López et al., 2017). It is believed that EOs is safe product. So that, high demand for them in agriculture. The most special and important area for applying EOs or their constituents is growth inhibition and reduction of phytopathogens. For example, the genus Xanthomonas (Gram-negative), causes disease in many plants including cereals. This fact makes Xanthomonas is one of the major problems in farming systems. Control of such plant diseases is extremely difficult and costly, as they can easily be spread from contaminated plants via rainwater, wind, birds, and insects (Sundin et al., 2016). Although few publications had documented on the activities of EOs against Xanthomonas, but latest report revealed that EOs applications was effective in inhibiting the growth of Xanthomonas (Sahu et al., 2018).

The farmer-researcher relationship in understanding of plant disease control measures is important for effective plant disease management. Farmers' knowledge on field diseases control by natural product or ginger EOs is exceptionally low. Therefore, there is an urgent need for a cooperation/collaboration between farmers and scientists on the use of ginger EOs for effective control plant diseases. Governments must provide incentives and emphasize on the need for extension workers and researchers to recognize and develop farmers' awareness on plant disease control using EOs. Such perspectives into the awareness of farmers about plant disease control with natural products such as ginger EOs can provide the basis for more collaborative management of plant disease control in the tropics.

Some studies have clearly shown that acceptance and support for the use of these natural products which enable farmers to enhance their overall farm management (disease control, cost reduction, and production performance). The work of Agarwal et al. (2001) demonstrated a strong control of insect growth and major antifungal activity against Rhizoctonia solani without compromising the quality of the environment (Sa-nguanpuag et al., 2008). To achieve a substantial reduction of harmful pathogenic loads, the use of ginger EOs is required through the implementation of a diverse range of treatment strategies. In vitro and open field agricultural practices (EOs-nanoemulsions technology) using their individual components showed antimicrobial activity against plant pathogens (Bajpai et al., 2011). Therefore, unwanted infections of plant diseases can be controlled by careful selection of EOs-nanotechnology system.

\section{EOs-Based Nanotechnology}

Different technologies and techniques have been developed to increase and boost agricultural productivity by developing new formulations of pesticides from natural plant products. Nowadays, society is seen as a technologized modern society, where technology advances will find the great solutions to human problems (Acharya and Pal, 2020). Nanotechnology has been relied upon in recent years to play a significant role in tropical food production, health and quality in the sense that the use of nanotechnology contributed to effective plant disease control. It is one of exciting field of science as well as benefiting technology in plant disease control by formulating natural products such as ginger EOs as natural pesticides to control tropical plant diseases (Echeverria and Albuquerque, 2019). Usually nanomaterials are made based on models for the enclosure of natural bioactive compounds which are particles with one or more dimensions with $100 \mathrm{~nm}$ or less. This can be achieved by integrating these natural products as nanomaterials. These nanomaterials in the form of polymeric NPs, liposomes, solid lipid NPs, and nanoemulsions comprise an inner liquid core surrounded by an outer polymer layer in which the active compounds are confined to a cavity and finally allow reaching the target area (Prasad et al., 2014). Likewise, nanospheres are solid colloidal fragments that incorporate, store, encapsulate or adsorb natural components like EOs into the polymer matrix.

Ginger EOs often exhibited excellent antimicrobial activity but their applications are very limited due to their low 


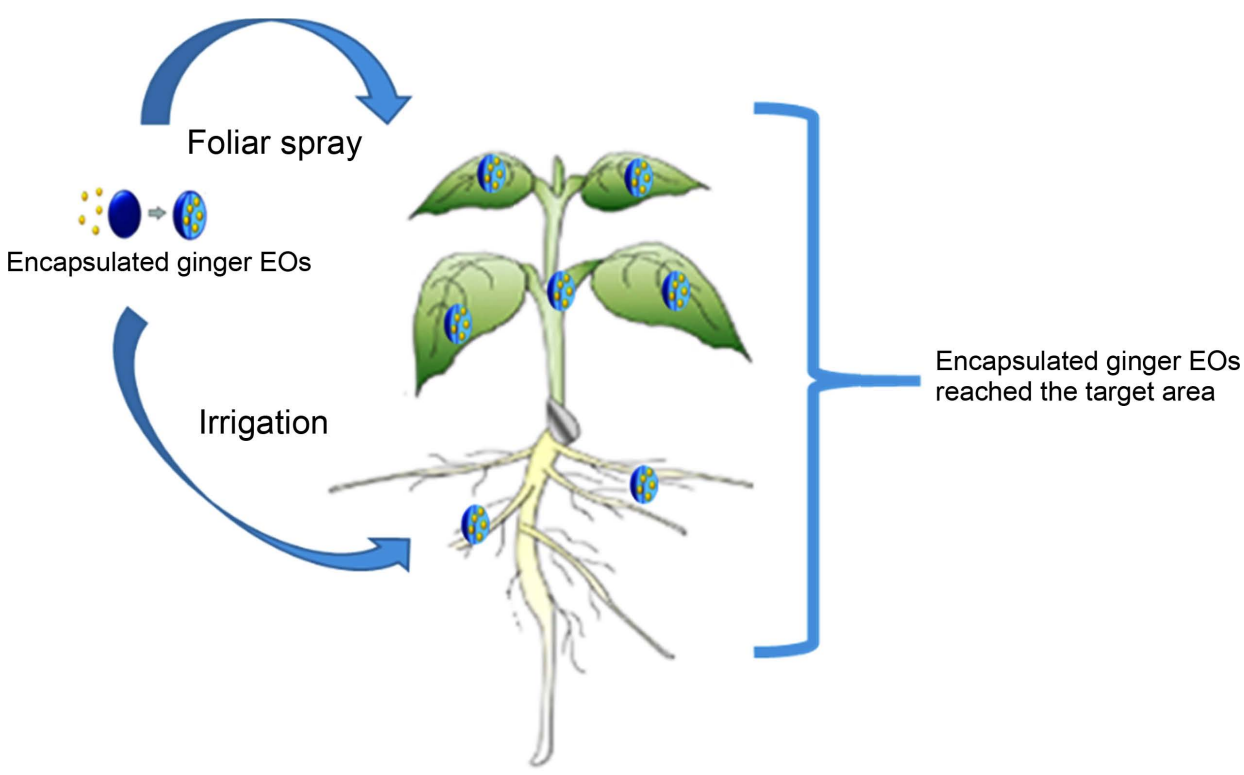

Fig. 4. Application of encapsulated ginger essential oils (EOs) with its physical and chemical stability to the target locations. Nanoemulsionrelated benefits include bioavailability, controlled release, and protection of EOs from environmental stresses. Their applications are promising agents that can be used in plant protection to improve the anti-microbial, antifungal, antiviral and pesticide activities of EOs. This may solve many agricultural problems in plant-pathogen interactions.

water solubility and high oxygen, moisture, heat and light susceptibility. Nanotechnological innovation has emerged as solutions to these emerging challenges, improving their stability, water solubility and shielding them from degradation. EOs delivery systems such as nanoemulsions, microemulsions, solid-lipid nanoparticles and liposomes are models for enclosure of such natural bioactive compounds to enhance antimicrobial activity (Pedro et al., 2013). Nanoemulsions are dispersions of nanoparticles consisting of two insoluble liquids, namely oil, and water, one of which is distributed by an emulsion-stabilizing surfactant on the other. Surfactants are required to formulate nanoemulsions for droplet size reduction, interfacial layer inflexibility, and droplet quality below $100 \mathrm{~nm}$ (Lim et al., 2012). The application of EOs are well engineered to create specific characteristics meant for appropriate applications (Khot et al., 2012) to control tropical plant diseases. The reduction to nanometric scale of droplet size raises the area of the substrate and it as well promote contact with microbial pathogen resulting in lysis and cell death. The components of EOs can access cell membrane pathways with their sizes, surface-to-volume ratios, physical and chemical stabilities, and degree of selectivity, thus setting the passage of EOs to reach their target locations (Fig. 4).

The emergence of EOs as one of the imperative tools for plant disease control in the tropics will also continue to be a driving force economically for changing the present agricultural practices to better. Novel delivery systems for plant protection, improvement and productivity of tropical crops have the potential to be increased with the use of nanotechnology-based EOs and hence will provide more affordable solution (Acharya and Pal, 2020). These encapsulation technologies and controlled methods of release have transformed the use of nanotechnology-based ginger EOs as an antibacterial for preservation of tropical crops (Prasad et al., 2014). It is a hybrid smart delivery systems which could only be released when needed, resulting in greater preservation of tropical crops and lower costs through the use of farm manpower (Nirmala and Nagarajan, 2017). At present, nanotechnology is one of the most promising disease control technologies for protection and preservation of tropical crops against bacterial and/or fungal pathogens. Some of the top companies in the world are focusing on formulating nanoscale pesticides for delivery via nanoencapsulation into the target host tissue. Many formulations are made to contain nanomaterials (Table 6). These materials dissolve well in water to enhance their activities. Thus, they are employed as nanoscale particles to constitute antimicrobial nanoparticle suspensions which can be conveniently combined with different media such as gels, liquids and creams (Prasad et al., 2014).

Past researches had revealed that different nanoparticles affect disease causing organisms, rodents, and insects. Therefore, it imperative to use nanoscale to prepare new formulations which are made from natural products such as EOs for pesticides, insecticides, and insect repellants (Rai and Ingle, 2012). The use of nanoparticles innovations in plant disease control can also solve many agricultural problems in plant-pathogen interactions (Ghormade et al., 2011). The research of Valentim et al. (2018) revealed that EOs-nanoemulsion is effective against Colossoma macropomum monogeneans. Likewise, nanoemulsions containing 


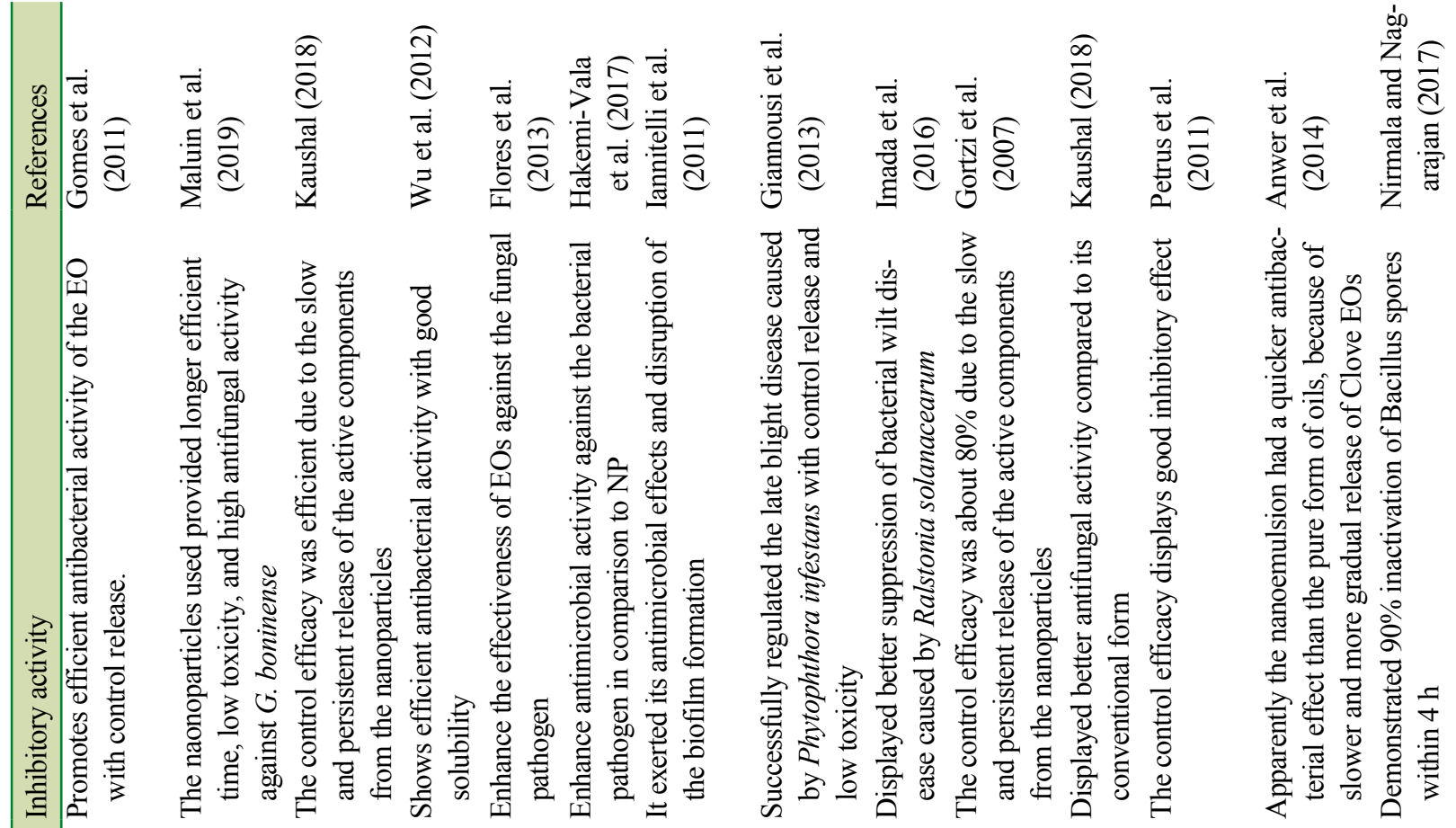

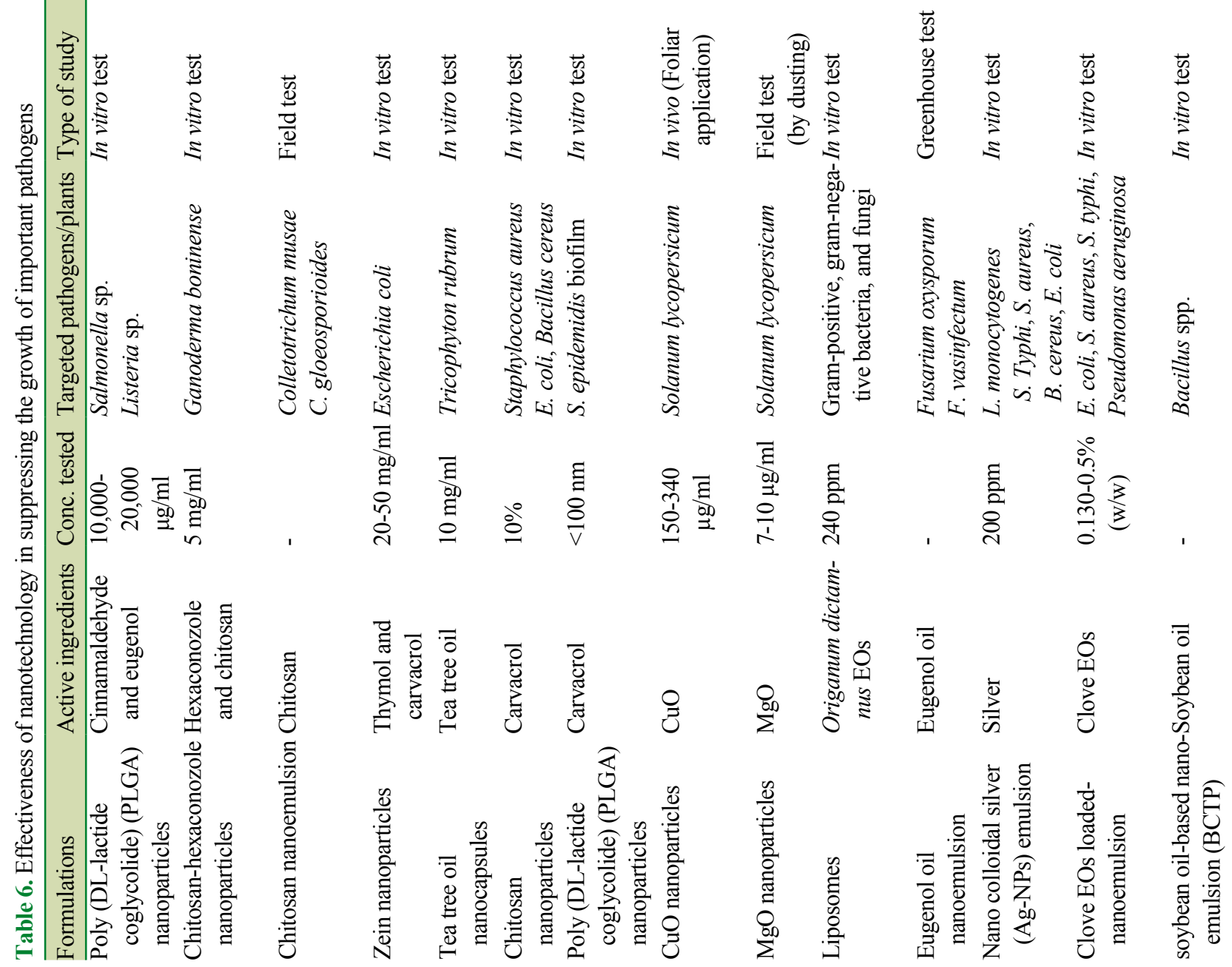




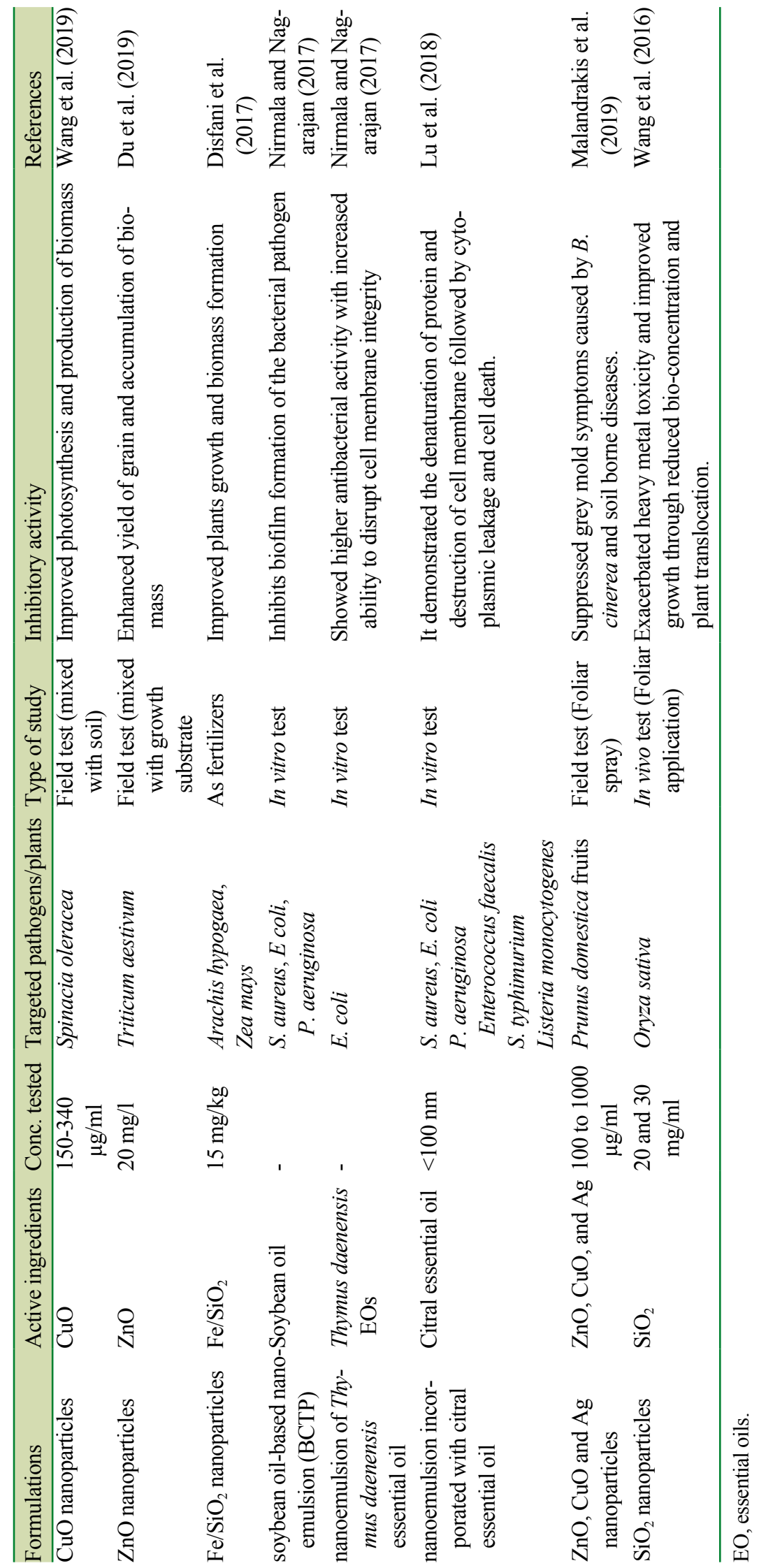


citral-EOs have the capability of disrupting and penetrating the lipid structure of the bacterial cell wall. It results in protein denaturation and cell membrane destruction followed by cytoplasmic leakage and conformational changes and cell death. Nanoemulsion composition significantly affects antimicrobial activities. A guided delivery system of functional molecules produced from EOs would function in the treatment of plant diseases (Lu et al., 2018). Mahdavi et al. (2018) revealed that polymeric nanofibers containing ginger EOs showed that because of the steady and continuous released of the effective components of EOs loaded onto nanofibers become more powerful.

Researches have demonstrated that nanotechnology are suitable carriers of active materials because they can be rapidly prepared, they have a simple structure, they have better thermodynamic stability, their cost of production low, and they can be mass produced (Echeverria and de Albuquerque, 2019). Nanotechnology-based systems have many advantages such as (1) higher ratio of surface to area and higher free energy making them efficient transport system because higher surface improves absorption rate and also reduces volatility, thus increasing bioavailability and active ingredient absorption, (2) no possible intrinsic creaming, flocculation, coalescence, and sedimentation, because they are thermodynamically and kinetically stable, (3) they reduce volatility, thus increasing absorption rate and amount, (4) their formulation can be applied as foams, creams, oils, and sprays, (5) their non-toxic, non-irritating nature of nanoemulsion provides basis for their application to protect and preserve tropical crops, (6) nanoemulsions can bring active ingredients of both hydrophilic and lipophilic parts to the desired site, (7) nanoemulsions protect the active ingredients against hydrolysis and oxidation because of oil-droplet encapsulation, and (8) development and application of nanoemulsions are economically viable compared with other delivery systems.

\section{Future Prospects and Conclusion}

Ginger EOs could be sustainable alternative for controlling tropical plant diseases. Being environmental friendly, the interest in the use of EOs in crop protection is increasing. The emergence of resistant bacteria and fungi pathogens to many antimicrobial agents is a major challenge in agriculture. Hence, new antimicrobials are needed. The use of ginger EOs in plant disease control will mitigate major agricultural problems in plant-pathogen interactions. Nevertheless, their use in agriculture has been limited by their relatively low water solubility and stability coupled with their high volatility. Nanotechnology is a groundbreaking technology with possible uses in agriculture. Furthermore, nanoparticles are attractive resources because they can solve the limitations of EOs such as light, humidity, and warm temperature. By exploiting EOs potentials and creating synergies between EOs and their constituents using state of the technologies, the problems of plant disease control in the tropics can be minimized.

The plant protection concept emphasizes production of safe crop with the least possible effect on the agro-ecosystem, discourage the use of chemical control measures, and supports the use of natural products, such as ginger EOs/ ginger Eos-based nanotechnology. Scientific evidences to support the use of both preventive and direct plant protection measures using natural products that may reduce uneconomic, unjustified chemical pesticide treatments, and reduction of adverse environmental and human health impacts are overdue. Sustainable plant protection entails the potential use of ginger EOs/ginger Eos-based nanotechnology for sustainable and effective plant disease control in the tropics.

\section{Conflicts of Interest}

No potential conflict of interest relevant to this article was reported.

\section{Acknowledgments}

The authors thank the staffs of Department of Plant Protection, Faculty of Agriculture, Universiti Putra Malaysia for their technical assistance. Special appreciation to the Ministry of Higher Education Malaysia for proving a research funding under Long-term Research Grant Scheme (LRGS/1/2019/UPM/2).

\section{References}

Abdel-Kader, M. M., Shaban, A. M. H. and El-Mougy, N. S. 2015. Bi-ological and chemical resistance inducers as seed priming for controlling faba bean root rot disease under field conditions. Int. J. Eng. Innov. Technol. 4:300-305.

Acharya, A. and Pal, P. K. 2020. Agriculture nanotechnology: translating research outcome to field applications by influencing environmental sustainability. NanoImpact 19:100232.

Agarwal, M., Walia, S., Dhingra, S. and Khambay, B. P. S. 2001. Insect growth inhibition, antifeedant and antifungal activity of compounds isolated/derived from Zingiber officinale Roscoe (ginger) rhizomes. Pest Manag. Sci. 57:289-300.

Akhtar, M. S., Swamy, M. K. and Sinniah, U. R. 2019. Natural bio-active compounds. Vol. 1. Springer Nature Singapore Pte 
Ltd., Singapore. 589 pp.

Al-Hetar, M. Y., Zainal Abidin, M. A., Sariah, M. and Wong, M. Y. 2011. Antifungal activity of chitosan against Fusarium oxysporum f. sp. cubense. J. Appl. Polym. Sci. 120:2434-2439.

Ali, B. H., Blunden, G., Tanira, M. O. and Nemmar, A. 2008. Some phytochemical, pharmacological and toxicological properties of ginger (Zingiber officinale Roscoe): a review of recent research. Food Chem. Toxicol. 46:409-420.

Alzoreky, N. S. and Nakahara, K. 2003. Antibacterial activity of extracts from some edible plants commonly consumed in Asia. Int. J. Food Microbiol. 80:223-230.

Anwer, M. K., Jamil, S., Ibnouf, E. O. and Shakeel, F. 2014. Enhanced antibacterial effects of clove essential oil by nanoemulsion. J. Oleo Sci. 63:347-54.

Arifullah, M., Vikram, P., Chiruvella, K. K., Shaik, M. M. and Abdullah Ripain, I. H. B. 2014. A review on Malaysian plants used for screening of antimicrobial activity. Annu. Res. Rev. Biol. 4:2088-2132.

Asfour, H. Z. 2018. Anti-quorum sensing natural compounds. $J$. Microsc. Ultrastruct. 6:1-10.

Awang, K., Ibrahim, H., Rosmy Syamsir, D., Mohtar, M., Mat Ali, R. and Azah Mohamad Ali, N. 2011. Chemical constituents and antimicrobial activity of the leaf and rhizome oils of Alpinia pahangensis Ridl., an endemic wild ginger from Peninsular Malaysia. Chem. Biodivers. 8:668-673.

Bajpai, V. K., Kang, S., Xu, H., Lee, S.-G., Baek, K.-H. and Kang, S. C. 2011. Potential roles of essential oils on controlling plant pathogenic bacteria Xanthomonas species: a review. Plant Pathol. J. 27:207-224.

Belliardo, F., Bicchi, C., Cordero, C., Liberto, E., Rubiolo, P. and Sgorbini, B. 2006. Headspace-solid-phase microextraction in the analysis of the volatile fraction of aromatic and medicinal plants. J. Chromatogr. Sci. 44:416-429.

Bhattarai, K., Pokharel, B., Maharjan, S. and Adhikari, S. 2018. Chemical constituents and biological activities of ginger rhizomes from three different regions of Nepal. J. Nutr. Diet. Probiotics 1:180005.

Bhavaniramya, S., Vishnupriya, S., Al-Aboody, M. S., Vijayakumar, R. and Baskaran, D. 2019. Role of essential oils in food safety: antimicrobial and antioxidant applications. Grain Oil Sci. Technol. 2:49-55.

Böhme, K., Barros-Velázquez, J., Calo-Mata, P. and Aubourg, S. P. 2014. Antibacterial, antiviral and antifungal activity of essential oils: mechanisms and applications. In: Antimicrobial compounds, eds. by T. Villa and P. Veiga-Crespo, pp. 51-81. Springer, Berlin, Germany.

Brusotti, G., Cesari, I., Dentamaro, A., Caccialanza, G. and Massolini, G. 2014. Isolation and characterization of bioactive compounds from plant resources: the role of analysis in the ethnopharmacological approach. J. Pharm. Biomed. Anal. 87:218-228.

Buttimer, C., McAuliffe, O., Ross, R. P., Hill, C., O’Mahony, J. and Coffey, A. 2017. Bacteriophages and bacterial plant diseases. Front. Microbiol. 8:34.
Bylaite, E., Roozen, J. P., Legger, A., Venskutonis, R. P. and Posthumus, M. A. 2000. Dynamic headspace-gas chromatography-olfactometry analysis of different anatomical parts of lovage (Levisticum officinale Koch.) at eight growing stages. $J$. Agric. Food Chem. 48:6183-6190.

Chiang, E. C. W., Yan, L. Y. and Ali, N. A. M. 2010. Composition and antibacterial activity of essential oils from leaves of Etlingera species (Zingiberaceae). Int. J. Adv. Sci. Arts 1:1-12.

Chouhan, S., Sharma, K. and Guleria, S. 2017. Antimicrobial activity of some essential oils: present status and future perspectives. Medicines (Basel) 4:58.

Dara, S. K. 2019. The new integrated pest management paradigm for the modern age. J. Integr. Pest Manag. 10:12.

Das, A., Kasoju, N., Bora, U. and Rangan, L. 2013. Chemicobiological investigation of rhizome essential oil of Zingiber moran: native to Northeast India. Med. Chem. Res. 22:43084315.

Debbarma, J., Kishore, P., Nayak, B. B., Kannuchamy, N. and Gudipati, V. 2013. Antibacterial activity of ginger, eucalyptus and sweet orange peel essential oils on fish-borne bacteria. $J$. Food Process. Preserv. 37:1022-1030.

De Melo, G. A. N., Grespan, R., Fonseca, J. P., Farinha, T. O., da Silva, E. L., Romero, A. L., Bersani-Amado, C. A. and Cuman, R. K. N. 2011. Inhibitory effects of ginger (Zingiber officinale Roscoe) essential oil on leukocyte migration in vivo and in vitro. J. Nat. Med. 65:241-246.

Dhanik, J., Arya, N. and Nand, V. 2017. A review on Zingiber officinale. J. Pharmacogn. Phytochem. 6:174-184.

Dhifi, W., Bellili, S., Jazi, S., Bahloul, N. and Mnif, W. 2016. Essential oils' chemical characterization and investigation of some biological activities: a critical review. Medicines (Basel) $3: 25$.

Disfani, M. N., Mikhak, A., Kassaee, M. Z. and Maghari, A. 2017. Effects of nano $\mathrm{Fe} / \mathrm{SiO}_{2}$ fertilizers on germination and growth of barley and maize. Arch. Agron. Soil Sci. 63:817826.

Donsi, F. and Ferrari, G. 2016. Essential oil nanoemulsions as antimicrobial agents in food. J. Biotechnol. 233:106-120.

Dorman, H. J. D. and Deans, S. G. 2000. Antimicrobial agents from plants: antibacterial activity of plant volatile oils. $J$. Appl. Microbiol. 88:308-316.

Du, W., Yang, J., Peng, Q., Liang, X. and Mao, H. 2019. Comparison study of zinc nanoparticles and zinc sulphate on wheat growth: from toxicity and zinc biofortification. Chemosphere 227:109-116.

Dwyer, D. J., Kohanski, M. A. and Collins, J. J. 2009. Role of reactive oxygen species in antibiotic action and resistance. Curr. Opin. Microbiol. 12:482-489.

Echeverria, J. and de Albuquerque, R. D. D. G. 2019. Nanoemulsions of essential oils: new tool for control of vector-borne diseases and in vitro effects on some parasitic agents. Medicines (Basel) 6:42.

El Asbahani, A., Miladi, K., Badri, W., Sala, M., Addi, E. H. A., Casabianca, H., El Mousadik, A., Hartmann, D., Jilale, A., Renaud, F. N. R. and Elaissari, A. 2015. Essential oils: from 
extraction to encapsulation. Int. J. Pharm. 483:220-243.

El-Baroty, G. S., Abd El-Baky, H. H., Farag, R. S. and Saleh, M. A. 2010. Characterization of antioxidant and antimicrobial compounds of cinnamon and ginger essential oils. Afr. J. Biochem. Res. 4:167-174.

Emmanuel, T., Aristide, B., Leopold, T., Benoît, N. M. and Joseph, M. T. 2013. Phytochemical screening, chemical composition and antimicrobial activity of Zingiber officinale essential oil of Adamaoua region (Cameroon). J. Chem. Pharm. Res. 5:296-301.

Ezraty, B., Gennaris, A., Barras, F. and Collet, J.-F. 2017. Oxidative stress, protein damage and repair in bacteria. Nat. Rev. Microbiol. 15:385-396.

Fan, S., Chang, J., Zong, Y., Hu, G. and Jia, J. 2018. GC-MS analysis of the composition of the essential oil from Dendranthema indicum var. Aromaticum using three extraction methods and two columns. Molecules 23:576.

Fitriady, M. A., Sulaswatty, A., Agustian, E., Salahuddin and Aditama, D. P. F. 2017. Steam distillation extraction of ginger essential oil: study of the effect of steam flow rate and time process. In: AIP Conference Proceedings, Vol. 1803, No. 1, ed. by S. Tursiloadi, p. 020032. AIP Publishing, Melville, NY, USA.

Flores, F. C., de Lima, J. A., Ribeiro, R. F., Alves, S. H., Rolim, C. M. B., Beck, R. C. R. and da Silva, C. B. 2013. Antifungal activity of nanocapsule suspensions containing tea tree oil on the growth of Trichophyton rubrum. Mycopathologia 175:281-286.

Ghormade, V., Deshpande, M. V. and Paknikar, K. M. 2011. Perspectives for nano-biotechnology enabled protection and nutrition of plants. Biotechnol. Adv. 29:792-803.

Giannousi, K., Avramidis, I. and Dendrinou-Samara, C. 2013. Synthesis, characterization and evaluation of copper based nanoparticles as agrochemicals against Phytophthora infestans. RSC Adv. 3:21743-21752.

Gomes, C., Moreira, R. G. and Castell-Perez, E. 2011. Poly(DLlactide-co-glycolide) (PLGA) nanoparticles with entrapped trans-cinnamaldehyde and eugenol for antimicrobial delivery applications. J. Food Sci. 76:N16-N24.

González Villa, T. and Veiga-Crespo, P. 2014. Antimicrobial compounds: current strategies and new alternatives. SpringerVerlag, Berlin, Germany. 316 pp.

Gortzi, O., Lala, S., Chinou, I. and Tsaknis, J. 2007. Evaluation of the antimicrobial and antioxidant activities of Origanum dictamnus extracts before and after encapsulation in liposomes. Molecules 3:932-945.

Gurjar, M. S., Ali, S., Akhtar, M. and Singh, K. S. 2012. Efficacy of plant extracts in plant disease management. Agric. Sci. 3:425-433.

Hajano, J.-U.-D., Lodhi, A. M., Pathan, M. A., Khanzada, M. A. and Shah, G. S. 2012. In-vitro evaluation of fungicides, plant extracts and bio-controlagents against rice blast pathogen Magnaporthe oryzae couch. Pak. J. Bot. 44:1775-1778.

Hakemi-Vala, M., Rafati, H., Aliahmadi, A. and Ardalan, A. 2017. Nanoemulsions: a novel antimicrobial delivery system.
In: Nano- and microscale drug delivery systems, ed. by A. Grumezescu, pp. 245-266. Elsevier Inc., Tehran, Iran.

Höferl, M., Stoilova, I., Wanner, J., Schmidt, E., Jirovetz, L., Trifonova, D., Stanchev, V. and Krastanov, A. 2015. Composition and comprehensive antioxidant activity of ginger (Zingiber officinale) essential oil from Ecuador. Nat. Prod. Commun. 10:1085-1090.

Huang, B., Wang, G., Chu, Z. and Qin, L. 2012. Effect of oven drying, microwave drying, and silica gel drying methods on the volatile components of ginger (Zingiber officinale Roscoe) by HS-SPME-GC-MS. Dry. Technol. 30:248-255.

Iannitelli, A., Grande, R., Di Stefano, A., Di Giulio, M., Sozio, P., Bessa, L. J., Laserra, S., Paolini, C., Protasi, F. and Cellini, L. 2011. Potential antibacterial activity of carvacrol-loaded poly(DL-lactide- co-glycolide) (PLGA) nanoparticles against microbial biofilm. Int. J. Mol. Sci. 12:5039-5051.

Imada, K., Sakai, S., Kajihara, H., Tanaka, S. and Ito, S. 2016. Magnesium oxide nanoparticles induce systemic resistance in tomato against bacterial wilt disease. Plant Pathol. 65:551560.

Inkson, B. J. 2016. Scanning electron microscopy (SEM) and transmission electron microscopy (TEM) for materials characterization. In Materials characterization using nondestructive evaluation (NDE) methods, pp. 17-43. Elsevier Ltd., Amsterdam, The Netherlands.

Jaafar, F. M., Osman, C. P., Ismail, N. H. and Awang, K. 2007. Analysis of essential oils of leaves, stems, flowers and rhizomes of Etlingera elatior (Jack) R. M. Smith. Malays. J. Anal. Sci. 11:269-273.

Jakribettu, R. P., Boloor, R., Bhat, H. P., Thaliath, A., Haniadka, R., Rai, M. P., George, T. and Baliga, M. S. 2016. Ginger (Zingiber officinale Rosc.) oils. In: Essentials oils in food preservation, flavor and safety, ed. by V. R. Preedy, pp. 447454. Academic Press, London, UK.

Joseph, R., Joseph, T. and Joseph, J. 2001. Volatile essential oil constituents of Alpinia smithiae (Zingiberaceae). Rev. Biol. Trop. 49:509-512.

Jugreet, B. S., Suroowan, S., Rengasamy, R. R. K. and Mahomoodally, M. F. 2020. Chemistry, bioactivities, mode of action and industrial applications of essential oils. Trends Food Sci. Technol. 101:89-105.

Kaushal, M. 2018. Role of microbes in plant protection using intersection of nanotechnology and biology. In: Nanobiotechnology applications in plant protection, eds. by K. A. AbdElsalam and R. Prasad, pp. 111-135. Springer International Publishing, Cham, Switzerland.

Kerekes, E.-B., Deák, E., Takó, M., Tserennadmid, R., Petkovits, T., Vágvölgyi, C. and Krisch, J. 2013. Anti-biofilm forming and anti-quorum sensing activity of selected essential oils and their main components on food-related micro-organisms. $J$. Appl. Microbiol. 115:933-942.

Khot, L. R., Sankaran, S., Maja, J. M., Ehsani, R. and Schuster, E. W. 2012. Applications of nanomaterials in agricultural production and crop protection: a review. Crop. Prot. 35:64-70.

Koch, W., Kukula-Koch, W., Marzec, Z., Kasperek, E., Wyszo- 
grodzka-Koma, L., Szwerc, W. and Asakawa, Y. 2017. Application of chromatographic and spectroscopic methods towards the quality assessment of ginger (Zingiber officinale) rhizomes from ecological plantations. Int. J. Mol. Sci. 18:452.

Koo, I., Shi, X., Kim, S. and Zhang, X. 2014. iMatch2: compound identification using retention index for analysis of gas chromatography-mass spectrometry data. J. Chromatogr. A 1337:202-210.

Kumari, A. J., Venkateshwarlu, G., Choukse, M. K. and Anandan, R. 2014. Effect of essential oil and aqueous extract of ginger (Zingiber officinale) on oxidative stability of fish oil-in-water emulsion. J. Food Process Technol. 6:412.

Lanzotti, V., Bonanomi, G. and Scala, F. 2013. What makes $A l$ lium species effective against pathogenic microbes? Phytochem. Rev. 12:751-772.

Lee, J.-E., Jung, M., Lee, S.-C., Huh, M.-J., Seo, S.-M. and Park, I.-K. 2020. Antibacterial mode of action of trans-cinnamaldehyde derived from cinnamon bark (Cinnamomum verum) essential oil against Agrobacterium tumefaciens. Pestic. Biochem. Physiol. 165:104546.

Lee, K. W., Omar, D., Abdan, K. and Wong, M. Y. 2016. Physiochemical characterization of nanoemulsion formulation of phenazine and their antifungal efficacy against Ganoderma boninense PER71 in vitro. Res. J. Pharm. Biol. Chem Sci. 7:3056-3066.

Li, Y.-X., Zhang, C., Pan, S., Chen, L., Liu, M., Yang, K., Zeng, X. and Tian, J. 2020. Analysis of chemical components and biological activities of essential oils from black and white pepper (Piper nigrum L.) in five provinces of southern China. LWT 117:108644.

Lim, C. J., Basri, M., Omar, D., Abdul Rahman, M. B., Salleh, A. B. and Raja Abdul Rahman, R. N. Z. 2012. Physicochemical characterization and formation of glyphosate-laden nanoemulsion for herbicide formulation. Ind. Crops Prod. 36:607613.

Liu, Q., Meng, X., Li, Y., Zhao, C.-N., Tang, G.-Y. and Li, H.-B. 2017. Antibacterial and antifungal activities of spices. Int. J. Mol. Sci. 18:1283.

López, E. I. C., Balcázar, M. F. H., Mendoza, J. M. R., Ortiz, A. D. R., Melo, M. T. O., Parrales, R. S. and Delgado, T. H. 2017. Antimicrobial activity of essential oil of Zingiber officinale Roscoe (Zingiberaceae). Am. J. Plant Sci. 8:1511-1524.

Lu, W.-C., Huang, D.-W., Wang, C.-C. R., Yeh, C.-H., Tsai, J.-C., Huang, Y.-T. and Li, P.-H. 2018. Preparation, characterization, and antimicrobial activity of nanoemulsions incorporating citral essential oil. J. Food Drug Anal. 26:82-89.

Lucas, G. C., Alves, E., Pereira, R. B., Perina, F. J. and de Souza, R. M. 2012. Antibacterial activity of essential oils on Xanthomonas vesicatoria and control of bacterial spot in tomato. Pesqui. Agropecu. Bras. 47:351-359.

Mahboubi, M. 2019. Zingiber officinale Rosc. essential oil, a review on its composition and bioactivity. Clin. Phytosci. 5:6.

Mahdavi, V., Rafiee-Dastjerdi, H., Asadi, A., Razmjou, J. and Fathi Achachlouei, B. 2018. Synthesis of Zingiber officinale essential oil-loaded nanofiber and its evaluation on the potato tuber moth, Phthorimaea operculella (Lepidoptera: Gelechiidae). J. Crop Prot. 7:39-49.

Malandrakis, A. A., Kavroulakis, N. and Chrysikopoulos, C. V. 2019. Use of copper, silver and zinc nanoparticles against foliar and soil-borne plant pathogens. Sci. Total Environ. 670:292-299.

Maluin, F. N., Hussein, M. Z., Yusof, N. A., Fakurazi, S., Idris, A. S., Hilmi, N. H. Z. and Daim, L. D. J. 2019. Preparation of chitosan-hexaconazole nanoparticles as fungicide nanodelivery system for combating Ganoderma disease in oil palm. Molecules 24:2498.

Mao, Q.-Q., Xu, X.-Y., Cao, S.-Y., Gan, R.-Y., Corke, H., Beta, T. and Li, H.-B. 2019. Bioactive compounds and bioactivities of ginger (Zingiber officinale Roscoe). Foods 8:185.

Marriott, P. J., Shellie, R. and Cornwell, C. 2001. Gas chromatographic technologies for the analysis of essential oils. $J$. Chromatogr. A 936:1-22.

McManus, P. S., Stockwell, V. O., Sundin, G. W. and Jones, A. L. 2002. Antibiotic use in plant agriculture. Annu. Rev. Phytopathol. 40:443-465.

Memar, M. Y., Ghotaslou, R., Samiei, M. and Adibkia, K. 2018. Antimicrobial use of reactive oxygen therapy: current insights. Infect. Drug Resist. 11:567-576.

Mesomo, M. C., Corazza, M. L., Ndiaye, P. M., Dalla Santa, O. R., Cardozo, L. and de Paula Scheer, A. 2013. Supercritical $\mathrm{CO}_{2}$ extracts and essential oil of ginger (Zingiber officinale R.): chemical composition and antibacterial activity. J. Supercrit. Fluids 80:44-49.

Mostafa, N. M. 2018. Antibacterial activity of ginger (Zingiber officinale) leaves essential oil nanoemulsion against the cariogenic Streptococcus mutans. J. Appl. Pharm. Sci. 8:34-41.

Nazzaro, F., Fratianni, F., Coppola, R. and De Feo, V. 2017. Essential oils and antifungal activity. Pharmaceuticals (Basel) 10:86.

Nazzaro, F., Fratianni, F., De Martino, L., Coppola, R. and De Feo, V. 2013. Effect of essential oils on pathogenic bacteria. Pharmaceuticals 6:1451-1474.

Nega, A. 2014. Review on concepts in biological control of plant pathogens. J. Biol. Agric. Healthc. 4:33-55.

Nikolic, M., Vasic, S., Djurdjevic, J., Stefanovic, O. and Comic, L. 2014. Antibacterial and anti-biofilm activity of ginger (Zingiber officinale (Roscoe)) ethanolic extract. Kragujev. J. Sci. 36:129-136.

Nirmala M, J. and Nagarajan, R. 2017. Recent research trends in fabrication and applications of plant essential oil based nanoemulsions. J. Nanomed. Nanotechnol. 8:434.

Nour, A. H., Yap, S. S. and Nour, A. H. 2017. Extraction and chemical compositions of ginger (Zingiber officinale Roscoe) essential oils as cockroaches repellent. Aust. J. Basic Appl. Sci. 11:1-8.

Onyenekwe, P. C. and Hashimoto, S. 1999. The composition of the essential oil of dried Nigerian ginger (Zingiber officinale Roscoe). Eur. Food Res. Technol. 209:407-410.

Pal, K. K. and Gardener, B. M. 2006. Biological control of plant pathogens. Plant Health Instr. 1:1-25. 
Panth, M., Hassler, S. C. and Baysal-Gurel, F. 2020. Methods for management of soilborne diseases in crop production. Agriculture 10:16.

Pedro, A. S., Santo, I. E., Silva, C. V., Detoni, C. and Albuquerque, E. 2013. The use of nanotechnology as an approach for essential oil-based formulations with antimicrobial activity. In: Microbial pathogens and strategies for combating them: science, technology and education, ed. by A. Médnez-Vilas, pp. 1364-1374. Formatex Research Center, Badajoz, Spain.

Petrus, E. M., Tinakumari, S., Chai, L. C., Ubong, A., Tunung, R., Elexson, N., Chai, L. F. and Son, R. 2011. A study on the minimum inhibitory concentration and minimum bactericidal concentration of nano colloidal silver on food-borne pathogens. Int. Food Res. J. 18:55-66.

Poli, J.-P., Guinoiseau, E., De Rocca Serra, D., Sutour, S., Paoli, M., Tomi, F., Quilichini, Y., Berti, L. and Lorenzi, V. 2018. Anti-quorum sensing activity of 12 essential oils on Chromobacterium violaceum and specific action of cis-cis-pmenthenolide from corsican Metha suaveolens sp. insularis. Molecules 23:2125.

Popović, Z., Matić, R., Bojović, S., Stefanović, M. and Vidaković, V. 2016. Ethnobotany and herbal medicine in modern complementary and alternative medicine: an overview of publications in the field of I\&C medicine 2001-2013. J. Ethnopharmacol. 181:182-192.

Prasad, R., Kumar, V. and Prasad, K. S. 2014. Nanotechnology in sustainable agriculture: present concerns and future aspects. Afr. J. Biotechnol. 13:705-713.

Rai, M. and Ingle, A. 2012. Role of nanotechnology in agriculture with special reference to management of insect pests. Appl. Microbiol. Biotechnol. 94:287-293.

Rajip, P., Sumiya, K. V., Dhanya S., Remya, K. and Narayanakutty, M. C. 2016. Inhibitory effect of plant extracts and plant oils on Xanthomonas oryzae pv oryzae, the bacterial blight pathogen of rice. Int. J. Appl. Nat. Sci. 5:71-76.

Ruiz, J., Ventanas, J. and Cava, R. 2001. New device for direct extraction of volatiles in solid samples using SPME. J. Agric. Food Chem. 49:5115-5121.

Saha, S., Garg, R., Biswas, A. and Rai, A. B. 2016. Bacterial diseases of rice: an overview. J. Pure Appl. Microbiol. 9:725-736.

Sahu, S. K., Zheng, P. and Yao, N. 2018. Niclosamide blocks rice leaf blight by inhibiting biofilm formation of Xanthomonas oryzae. Front. Plant Sci. 9:408.

Sa-nguanpuag, K., Kanlayanarat, S. and Tanprasert, K. 2008. Applications of volatiles in ginger essential oil can reduce microorganisms in shredded green papaya. Acta Hortic. 804:439444.

Sasidharan, I. and Menon, A. N. 2010. Comparative chemical composition and antimicrobial activity fresh and dry ginger oils (Zingiber officinale Roscoe). Int. J. Curr. Pharm. Res. 2:40-43.

Sendanayake, L. R., Sylvester, T. P., De Silva, U. H. A. J., Dissanayake, D. R. R. P., Daundasekera, D. M. K. C. and Sooriyapathirana, S. D. S. S. 2017. Consumer preference, antibacterial activity and genetic diversity of ginger (Zingiber officinale Roscoe) cultivars grown in Sri Lanka. J. Agric. Sci. 12:207-221.

Şener, N., Özkinali, S., Gür, M., Güney, K., Özkan, O. E. and Khalifa, M. M. 2017. Determination of antimicrobial activity and chemical composition of pimento and ginger essential oil. Indian J. Pharm. Educ. Res. 51:S230-S233.

Shao, Y., Marriott, P., Shellie, R. and Hügel, H. 2003. Solid-phase micro-extraction: comprehensive two-dimensional gas chromatography of ginger (Zingiber officinale) volatiles. Flavour Fragr. J. 18:5-12.

Sharifi-Rad, J., Sureda, A., Tenore, G. C., Daglia, M., SharifiRad, M., Valussi, M., Tundis, R., Sharifi-Rad, M., Loizzo, M. R., Oluwaseun Ademiluyi, A., Sharifi-Rad, R., Ayatollahi, S. A. and Iriti, M. 2017a. Biological activities of essential oils: from plant chemoecology to traditional healing systems. Molecules 22:70.

Sharifi-Rad, M., Varoni, E. M., Salehi, B., Sharifi-Rad, J., Matthews, K. R., Ayatollahi, S. A., Kobarfard, F., Ibrahim, S. A., Mnayer, D., Zakaria, Z. A., Sharifi-Rad, M., Yousaf, Z., Iriti, M., Basile, A. and Rigano, D. 2017b. Plants of the genus Zingiber as a source of bioactive phytochemicals: from tradition to pharmacy. Molecules 22:2145.

Sharma, P. K., Singh, V. and Ali, M. 2016. Chemical composition and antimicrobial activity of fresh rhizome essential oil of Zingiber officinale Roscoe. Pharmacogn. J. 8:185-190.

Soylu, E. M., Soylu, S. and Kurt, S. 2006. Antimicrobial activities of the essential oils of various plants against tomato late blight disease agent Phytophthora infestans. Mycopathologia 161:119-128.

Sundin, G. W., Castiblanco, L. F., Yuan, X., Zeng, Q. and Yang, C.-H. 2016. Bacterial disease management: challenges, experience, innovation and future prospects: challenges in bacterial molecular plant pathology. Mol. Plant Pathol. 7:15061518.

Tao, C., Wang, Y., Zhang, X., Li, L., Wu, Y., Han, X., Jiang, X. and Lv, Z. 2019. Mechanism of action of essential oils extracted from bamboo (Phyllostachys heterocycla cv. pubescens) leaves: chemical composition and antimicrobial activity against four food-related microorganisms. BioResources 14:1419-1434.

Tariq, S., Wani, S., Rasool, W., Shafi, K., Bhat, M. A., Prabhakar, A., Shalla, A. H. and Rather, M. A. 2019. A comprehensive review of the antibacterial, antifungal and antiviral potential of essential oils and their chemical constituents against drugresistant microbial pathogens. Microb. Pathog. 134:103580.

Trimanto, T. and Hapsari, L. 2018. Short communication: a new record of Etlingera megalocheilos (Griff.) A.D. Poulsen (Zingiberaceae) in Sulawesi, Indonesia. Biodiversitas 19:1227-1235.

Vairappan, C. S., Nagappan, T. and Palaniveloo, K. 2012. Essential oil composition, cytotoxic and antibacterial activities of five Elingera species from Borneo. Nat. Prod. Commun. 7:239-242.

Valentim, D. S. S., Duarte, J. L., Oliveira, A. E. M. F. M., Cruz, R. A. S., Carvalho, J. C. T., Conceição, E. C., Fernandes, C. P. 
and Tavares-Dias, M. 2018. Nanoemulsion from essential oil of Pterodon emarginatus (Fabaceae) shows in vitro efficacy against monogeneans of Colossoma macropomum (Pisces: Serrasalmidae). J. Fish Dis. 41:443-449.

Vasireddy, L., Bingle, L. E. H. and Davies, M. S. 2018. Antimicrobial activity of essential oils against multidrug-resistant clinical isolates of the Burkholderia cepacia complex. PLoS ONE 13:e0201835.

Vatansever, F., de Melo, W. C. M. A., Avci, P., Vecchio, D., Sadasivam, M., Gupta, A., Chandran, R., Karimi, M., Parizotto, N. A., Yin, R., Tegos, G. P. and Hamblin, M. R. 2013. Antimicrobial strategies centered around reactive oxygen species - bactericidal antibiotics, photodynamic therapy, and beyond. FEMS Microbiol. Rev. 2:1-35.

Wang, S., Wang, F., Gao, S. and Wang, X. 2016. Heavy metal accumulation in different rice cultivars as influenced by foliar application of nano-silicon. Water Air Soil Pollut. 227:228.

Wang, Y., Lin, Y., Xu, Y., Yin, Y., Guo, H. and Du, W. 2019. Divergence in response of lettuce (var. ramosa Hort.) to copper oxide nanoparticles/microparticles as potential agricultural fertilizer. Environ. Pollut. Bioavailab. 31:80-84.

Winterbourn, C. C. 2008. Reconciling the chemistry and biology of reactive oxygen species. Nat. Chem. Biol. 4:278-286.

Wonni, I., Ouedraogo, S. L., Ouedraogo, I. and Sanogo, L. 2016. Antibacterial activity of extracts of three aromatic plants from Burkina Faso against rice pathogen, Xanthomanas oryzae. Afr. J. Microbiol. Res. 10:681-686.

Wu, K., Lin, Y., Chai, X., Duan, X., Zhao, X. and Chun, C. 2019. Mechanisms of vapor-phase antibacterial action of essential oil from Cinnamomum camphora var. linaloofera Fujita against Escherichia coli. Food Sci. Nutr. 7:2546-2555.

Wu, Y., Luo, Y. and Wang, Q. 2012. Antioxidant and antimicrobial properties of essential oils encapsulated in zein nanoparticles prepared by liquid-liquid dispersion method. $L W T$ 48:283-290.

Yang, Z.-N., Yang, W., Peng, Q., He, Q., Feng, Y., Luo, S. and Yu, Z. 2009. Volatile phytochemical composition of rhizome of ginger after extraction by headspace solid-phase microextraction, petrol ether extraction and steam distillation extraction. Bangladesh J. Pharmacol. 4:136-143.

Zhang, D., Gan, R.-Y., Zhang, J.-R., Farha, A. K., Li, H.-B., Zhu, F, Wang, X.-H. and Corke, H. 2020. Antivirulence properties and related mechanisms of spice essential oils: a comprehensive review. Compr. Rev. Food Sci. Food Saf. 19:1018-1055. 